\title{
Nanoscale Metallic Iron for Environmental Remediation: Prospects and Limitations
}

\author{
Chicgoua Noubactep • Sabine Caré • \\ Richard Crane
}

Received: 23 June 2011 / Accepted: 6 September 2011 /Published online: 22 September 2011

(C) The Author(s) 2011. This article is published with open access at Springerlink.com

\begin{abstract}
The amendment of the subsurface with nanoscale metallic iron particles $\left(\right.$ nano- $\mathrm{Fe}^{0}$ ) has been discussed in the literature as an efficient in situ technology for groundwater remediation. However, the introduction of this technology was controversial and its efficiency has never been univocally established. This unsatisfying situation has motivated this communication whose objective was a comprehensive discussion of the intrinsic reactivity of nano- $\mathrm{Fe}^{0}$ based on the contemporary knowledge on the mechanism of
\end{abstract}

C. Noubactep $(\square)$

Angewandte Geologie, Universität Göttingen,

Goldschmidtstraße 3,

37077 Göttingen, Germany

e-mail: cnoubac@gwdg.de

S. Caré

Université Paris-Est, Laboratoire Navier,

(ENPC/IFSTTAR/CNRS),

2 allée Kepler,

77420 Champs sur Marne, France

e-mail: sabine.care@ifsttar.fr

R. Crane

Interface Analysis Centre, University of Bristol,

121 St. Michael's Hill,

Bristol BS2 8BS UK

e-mail: Richard.Crane@bristol.ac.uk

C. Noubactep

Kultur und Nachhaltige Entwicklung CDD e.V., Postfach 1502,

37005 Göttingen, Germany contaminant removal by $\mathrm{Fe}^{0}$ and a mathematical model. It is showed that due to limitations of the mass transfer of nano- $\mathrm{Fe}^{0}$ to contaminants, available concepts cannot explain the success of nano- $\mathrm{Fe}^{0}$ injection for in situ groundwater remediation. It is recommended to test the possibility of introducing nano- $\mathrm{Fe}^{0}$ to initiate the formation of roll-fronts which propagation would induce the reductive transformation of both dissolved and adsorbed contaminants. Within a roll-front, $\mathrm{Fe}^{\mathrm{II}}$ from nano- $\mathrm{Fe}^{0}$ is the reducing agent for contaminants. $\mathrm{Fe}^{\mathrm{II}}$ is recycled by biotic or abiotic $\mathrm{Fe}^{\mathrm{III}}$ reduction. While the roll-front concept could explain the success of already implemented reaction zones, more research is needed for a science-based recommendation of nano$\mathrm{Fe}^{0}$ for subsurface treatment by roll-fronts.

Keywords Environmental remediation · Material reactivity $\cdot$ Nanoscale iron $\cdot$ Roll-front $\cdot$ Zerovalent iron

\section{Introduction}

The development of new methods and materials for environmental remediation is a real challenge for the scientific community. Such technologies will only be adopted by industry if they can exhibit marked improvements in efficiency, affordability or ecocompatibility compared with conventional techniques. The use of metallic iron $\left(\mathrm{Fe}^{0}\right)$ in subsurface reactive permeable barriers has been identified as such a technology (Gillham and O'Hannesin 1991, 1994; Matheson and Tratnyek 1994; Blowes et al. 1997; 
O'Hannesin and Gillham 1998). Since this discovery almost 20 years ago, extensive research of the $\mathrm{Fe}^{\mathrm{O}}$ / $\mathrm{H}_{2} \mathrm{O}$ system has been performed in an attempt to understand the controlling mechanisms behind the remediation of redox-amenable contaminant species using $\mathrm{Fe}^{0}$-based materials (Scherer et al. 2000; Henderson and Demond 2007; Bartzas and Komnitsas 2010; Gillham 2010; Li and Benson 2010; Noubactep 2010a, b; Noubactep and Caré 2010a; Kim et al. 2010; Comba et al. 2011; Courcelles et al. 2011; Gheju 2011; Jeen et al. 2011; Noubactep 2011a). Two different tools are commonly used to optimise the efficiency of $\mathrm{Fe}^{0}$ for aqueous contaminant removal: (1) reducing the particle size of $\mathrm{Fe}^{0}$ down to the nanoscale (nano-Fe ${ }^{0}$ ) (Wang and Zhang 1997; Ponder et al. 2000) and (2) using bimetallic systems (Muftikian et al. 1995; Korte et al. 2000). In recent years, there has been considerable interest into combining the two methods (Schrick et al. 2002; Karn et al. 2009; Nagpal et al. 2010; Chen et al. 2011; Mossa et al. 2011).

Since the original proof of concept study into the application of nano- $\mathrm{Fe}^{0}$ for water treatment at Lehigh University, USA (Wang and Zhang 1997), research within this field has boomed. On August 20th 2011, a search at "ACS publications", "Science Direct" (Elsevier journals), and "Springer journals" using key words "nanoscale" and "zerovalent iron" yielded 740 peer-reviewed articles (Table 1). As shown in Table 1, 234 articles have already been published in the first 7 months of 2011 by the three selected publishers. This clearly demonstrates the interest within academia for this technology.

In recent years, several review articles and critical views on nano- $\mathrm{Fe}^{0}$ for environmental remediation have been published (Zhang et al. 1998; Gillham

Table 1 Results of a web-search for three relevant publishers demonstrating the current interest within academia for the nano-Fe ${ }^{0}$ technology (search: 20 August 2011)

\begin{tabular}{llrr}
\hline Publisher & \multicolumn{2}{l}{ Search's results } & \\
\cline { 2 - 4 } & Period & Total & 2011 \\
\hline ACS publications & 2004 to 2011 & 263 & 96 \\
Elsevier journals & 1993 to 2011 & 392 & 112 \\
Springer journals & 2003 to 2011 & 85 & 26 \\
& Total & 740 & 234 \\
\hline
\end{tabular}

2003; Zhang 2003; Li et al. 2006; Macé 2006; Macé et al. 2006; Tratnyek and Johnson 2006; Karn et al. 2009; Pradeep and Anshup 2009; Agarwal and Joshi 2010; Gillham 2010; Müller and Nowack 2010; Noubactep and Caré 2010b; Cullen et al. 2011; Noubactep 2011b; Peralta-Videa et al. 2011; Shi et al. 2011; Truex et al. 2011a, b). However, the original discussion on the suitability of nano- $\mathrm{Fe}^{0}$ for in situ field applications (Gillham 2003, 2010) has not been satisfactorily addressed (Macé 2006; Noubactep 2011b). Moreover, a recent comparison between field applications of $\mathrm{Fe}^{0}$ of different particle sizes (nanometres, micrometres, and millimetres) for field applications has clearly demonstrated the superiority of $\mathrm{mm}$ $\mathrm{Fe}^{0}$ (average efficacy 97\%) (Comba et al. 2011). The decreasing order of reactivity was mm-Fe ${ }^{0}(97 \%)>\mu \mathrm{m}$ $\mathrm{Fe}^{0}(91 \%)>$ nano-Fe ${ }^{0}$ (65\%). Expectably, the lower efficiency of nano- $\mathrm{Fe}^{0}$ is due to their high reactivity (Gillham 2003, 2010; Noubactep and Caré 2010b). Therefore, the question arises on the fundamental necessity to further increase the reactivity of nano- $\mathrm{Fe}^{0}$ by using a noble metal combination.

\subsection{The Problem}

Nano- $\mathrm{Fe}^{0}$ technology for environmental remediation was introduced as an alternative to the conventional $\mathrm{Fe}^{0}$ walls mostly for inaccessible aquifers (Masciangioli and Zhang 2003; Li et al. 2006). The very small particle size of nano- $\mathrm{Fe}^{0}(1-100 \mathrm{~nm})$ would allow the material to penetrate deep into soil networks (Ghauch et al. 2009; Karn et al. 2009; Comba et al. 2011; Gheju 2011; Truex et al. 2011a, b).

Due to the exponential relationship between specific surface area (SSA) and radius $(R=d / 2)$ of a perfectly spherical object $\left(\mathrm{SSA}=4 \pi R^{2}\right)$, as a rule, a decrease in $\mathrm{Fe}^{0}$ particle size increases the surface area per gram by up to three orders of magnitude (Macé et al. 2006; Chen et al. 2011). In other words, the inverse relationship between $\mathrm{Fe}^{0}$ particle size and reactivity is due to a greater density of reactive sites on the particle surface at smaller scale. The following three claims have been made with regard to the use of nano- $\mathrm{Fe}^{0}$ for aqueous contaminant removal (Comba et al. 2011): (1) some aqueous contaminant species that have been proven as unsuccessful for remediation using $\mu \mathrm{m}-\mathrm{Fe}^{0}$ and $\mathrm{mm}-\mathrm{Fe}^{0}$ can be effectively removed using nano$\mathrm{Fe}^{0}$, (2) nano- $\mathrm{Fe}^{0}$ can be used for more rapid 
degradation of contaminants, and (3) the formation of some undesirable by-products during remediation using $\mu \mathrm{m}$ - and $\mathrm{mm}-\mathrm{Fe}^{0}$ can be avoided by using nano- $\mathrm{Fe}^{0}$. Such processes whilst correct are all linked to the greater reactivity that nano- $\mathrm{Fe}^{0}$ possesses due to its size (reactive surface area). When performed in conditions without a large nano$\mathrm{Fe}^{0}$ stoichiometric excess, e.g. a system analogous to the environment, it may prove that such claims will be unfounded (Nagpal et al. 2010; Noubactep and Caré 2010b; Noubactep 2011b; Sakulchaicharoen et al. 2010; Nagpal et al. 2011).

An undisputed drawback with regards to the use of nano- $\mathrm{Fe}^{0}$ for environmental applications is their strong tendency to aggregate and adhere to solid surfaces (Li et al. 2006; Tratnyek and Johnson 2006; Karn et al. 2009; Sakulchaicharoen et al. 2010; Comba et al. 2011; Gheju 2011; Truex et al. 2011a, b). Karn et al. (2009) listed some parameters that influence nano- $\mathrm{Fe}^{0}$ adsorption onto soil and aquifer materials: (1) the surface chemistry of soil and $\mathrm{Fe}^{0}$ particles, (2) the groundwater chemistry (e.g. ionic strength, $\mathrm{pH}$ and presence of natural organic matter), and (3) the hydrodynamic conditions (pore size, porosity, flow velocity and degree of mixing or turbulence). Several methods have been developed for the stabilization of nano- $\mathrm{Fe}^{0}$ particles over the past decade and proven efficient to sustain the reactivity of nano- $\mathrm{Fe}^{0}$ (Karn et al. 2009; Sakulchaicharoen et al. 2010; Comba et al. 2011; Gheju 2011). One factor that has been overlooked, however, is the impact volumetric expansion has on the mobility of (1) residual $\mathrm{Fe}^{0}$, (2) primary corrosion products $\left(\mathrm{Fe}^{\mathrm{II}}\right.$ and $\mathrm{H}_{2}$ ) and contaminants. The volume of any corrosion product (Fe hydroxide or oxide) is higher than that of the original metal $\left(\mathrm{Fe}^{0}\right)$. The ratio between the volume of expansive corrosion product and the volume of iron consumed in the corrosion process is called "rust expansion coefficient" $(\eta)$ (Anstice et al. 1993; Caré et al. 2008; Zhao et al. 2011). Volumetric corrosion products are likely to: (1) contribute to porosity loss, (2) impact the retention of contaminants and transformation products, and (3) increase the particle agglomeration.

Another area of heightened research is with regard to the determining the toxicity of nano- $\mathrm{Fe}^{0}$, with mixed results reported (Grieger et al. 2010; Gheju 2011). For example, Barnes et al. (2010) reported minimal change to the structure of a river water community due to the addition of nano- $\mathrm{Fe}^{0}$ while Diao and Yao (2009) reported nano- $\mathrm{Fe}^{0}$ particles as highly cytotoxic towards both gram-positive and gram-negative bacteria species.

While taking into account all known influencing parameters, the following seven features have to be systematically studied in order to optimise the general applicability of this technique (Karn et al. 2009; Tervonen et al. 2009; Gheju 2011): (1) mobility changes due to nano- $\mathrm{Fe}^{0}$ volumetric expansion during corrosion, (2) the bioavailability of $\mathrm{Fe}^{0}$ and corrosion products $\left(\mathrm{Fe}^{\mathrm{II}} / \mathrm{Fe}^{\mathrm{III}}\right.$ species, $\left.\mathrm{H} / \mathrm{H}_{2}\right)$, (3) the ecotoxicity of $\mathrm{Fe}^{0}$ and its corrosion products, (4) the bioaccumulation of $\mathrm{Fe}^{0}$ and its corrosion products, (5) the translocation potential of nano- $\mathrm{Fe}^{0},(6)$ the long-term reactivity of nano- $\mathrm{Fe}^{0}$ particles and (7) the speciation, persistence and fate of contaminants and their transformation products. A major contributing factor to the latter point is that little is known (compared to permeable reactive barrier technologies) about the extent contaminants are removed via size exclusion using nano- $\mathrm{Fe}^{0}$.

Only when all seven "operational drivers" have been determined can the global community have full faith in the technology.

\subsection{Objectives of the Study}

The present communication is focused on the "field persistence" or reactive "life span" of nano-Fe ${ }^{0}$ particles. For in situ applications, a keen understanding of nano- $\mathrm{Fe}^{0}$ reactive fate is essential for effective and prudent site clean-up. The knowledge of which is likely to largely underpin decisions as to (1) the choice of material selected, (2) the mechanism of application and (3) the strategy (if any) for repeated treatments.

In the current work, a multidisciplinary approach is used to analyse the relationship between nano- $\mathrm{Fe}^{0}$ reactivity and its performance for in situ field applications. The discussion is based on the contemporary knowledge of the mechanism of aqueous contaminant removal by $\mathrm{Fe}^{0}$ (Noubactep 2007, 2008, 2010c, 2011d, e). Much of the impetus for this work has come from the work of Noubactep and Caré (2010b) who have challenged the concept that nano$\mathrm{Fe}^{0}$ is a strong reducing agent for contaminant reductive transformation. 


\section{Nanoscale Metallic Iron for Environmental Remediation}

To date, nano- $\mathrm{Fe}^{0}$ particles have been reported as largely successful for water and soil treatment (Pradeep and Anshup 2009; Agarwal and Joshi 2010; Litter et al. 2010; Comba et al. 2011; Crane et al. 2011). A wide variety of redox-amenable organic and inorganic species and nonreducible species (e.g. $\mathrm{Cd}$ and $\mathrm{Zn}$ ) have been efficiently treated. Similar to $\mu \mathrm{m}$ - and $\mathrm{mm}-\mathrm{Fe}^{0}$, adsorption is considered important only for non-reducible species (Celebi et al. 2007; Li and Zhang 2007; Noubactep 2007, 2008, 2010c; Boparai et al. 2011; Noubactep 2011c, d; Xiao et al. 2011). For example, Boparai et al. (2011) reported that heavy metals are either reduced (e.g. $\mathrm{Cu}^{2+}$ and $\mathrm{Ag}^{2+}$ ) at, or directly adsorbed (e.g. $\mathrm{Zn}^{2+}$ and $\mathrm{Cd}^{2+}$ ) onto the $\mathrm{Fe}^{0}$ surface. They further argued that "the controlling mechanism is a function of the standard redox potential of the contaminant". Recent work has however challenged this concept (Noubactep 2010c, 2011b, d, e), which is explained below.

\subsection{Contaminant Reduction by Nano-Fe ${ }^{0}$}

The chemical reaction between $\mathrm{Fe}^{0}$ and redoxamenable aqueous species is considered to involve three steps: (1) direct electron transfer from $\mathrm{Fe}^{0}$ at the metal surface or through a conductive oxide film on $\mathrm{Fe}^{0}$ (direct reduction), (2) catalyzed hydrogenolysis by the $\mathrm{H} / \mathrm{H}_{2}$ (indirect reduction mechanism 1) and (3) reduction by $\mathrm{Fe}^{\mathrm{II}}$ species resulting from $\mathrm{Fe}^{0}$ corrosion (indirect reduction mechanism 2). In this constellation, $\mathrm{H}_{2}$ is supposed to result from $\mathrm{H}_{2} \mathrm{O}$ reduction during anoxic iron corrosion (Reardon et al. 2008; Chen et al. 2011). However, evidence exists in the literature, e.g. Stratmann and Müller (1994), that even under external oxic conditions, $\mathrm{Fe}^{0}$ is oxidized by $\mathrm{H}_{2} \mathrm{O}$ (or more precisely by $\mathrm{H}^{+}$) and $\mathrm{O}_{2}$ by $\mathrm{Fe}^{\mathrm{II}}$ (Table 2). Despite the significant reaction rate exhibited by nano- $\mathrm{Fe}^{0}$ due to its high surface area, such processes are considered to occur (discounting any quantum size effects) independent of particle size.

Table 2 summarizes the half reactions for the aqueous oxidation of $\mathrm{Fe}^{0}$ under both anoxic and oxic conditions. Thermodynamically, the major cathodic reaction depends on the availability of molecular $\mathrm{O}_{2}$ $\left(E^{0}=0.81 \mathrm{~V}\right)$. In the absence of $\mathrm{O}_{2}, \mathrm{Fe}^{0}$ is oxidized by $\mathrm{H}^{+}\left(E^{0}=0.00 \mathrm{~V}\right)$. It can therefore be stated that the rate of $\mathrm{Fe}^{0}$ oxidation is dictated by the concentration
Table 2 Relevant redox couples for the process of aqueous $\mathrm{Fe}^{0}$ dissolution and oxide scale formation in a passive remediation $\mathrm{Fe}^{0} / \mathrm{H}_{2} \mathrm{O}$ system. These processes are thermodynamically the same for all $\mathrm{Fe}^{0}$ particle sizes. Observed differences are due to kinetics aspects

\begin{tabular}{llll}
\hline Electrode reactions & & & Eq. \\
\hline $\mathrm{Fe}^{0}$ & $\Leftrightarrow$ & $\mathrm{Fe}^{2+}+2 \mathrm{e}^{-}$ & (I) \\
Oxic conditions & & & \\
$\mathrm{O}_{2}+2 \mathrm{H}_{2} \mathrm{O}+4 \mathrm{e}^{-}$ & $\Leftrightarrow$ & $4 \mathrm{OH}^{-}$ & (IIa) \\
$2 \mathrm{H}_{2} \mathrm{O}+2 \mathrm{e}^{-}$ & $\Leftrightarrow$ & $\mathrm{H}_{2}+2 \mathrm{OH}^{-}$ & (IIb) \\
$\mathrm{Anoxic} \mathrm{conditions}$ & & & \\
$\mathrm{O}_{2}+4 \mathrm{H}^{+}+4 \mathrm{e}^{-}$ & $\Leftrightarrow$ & $2 \mathrm{H}_{2} \mathrm{O}$ & \\
$2 \mathrm{H}^{+}+2 \mathrm{e}^{-}$ & $\Leftrightarrow$ & $\mathrm{H}_{2}$ & (IIIa) \\
\hline
\end{tabular}

These processes are thermodynamically the same for all $\mathrm{Fe}^{0}$ particle sizes. Observed differences are due to kinetics aspects

of dissolved $\mathrm{O}_{2}, \mathrm{H}^{+}$and $\mathrm{H}_{2} \mathrm{O}$ in proximity to $\mathrm{Fe}^{0}$ surfaces. Le Chatelier's principle also states that the consumption of $\mathrm{Fe}^{\mathrm{II}}$ (via oxidation to $\mathrm{Fe}^{\mathrm{III}}$ ) will also result in an increase in $\mathrm{Fe}^{0}$ oxidation.

The electrode potential of the redox couple $\mathrm{Fe}^{\mathrm{II}} / \mathrm{Fe}^{0}$ is $-0.44 \mathrm{~V}$, a value which is independent of the particle size (nanometre, micrometre or millimetre). The value $-0.44 \mathrm{~V}$ is considered largely unchanged due to the presence of alloying materials (e.g. low alloy steel and bimetallic systems).

As a consequence, statements including " $n a n o-F e$ are more reactive than $\mu m-F e^{0}$ and $m m-F e^{0 \text { " }}$ are misleading; as the reactivity of $\mathrm{Fe}^{0}$ (discounting quantum size effects), is independent of the particle size. Any enhanced reactivity reported is likely to be due to the significantly high surface area of nano- $\mathrm{Fe}^{0}$ compared with other forms. A second statement "bimetallic nano- $\mathrm{Fe}^{0}$ is more reactive that monome-

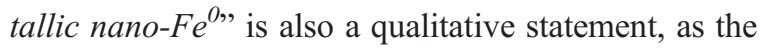
reactivity of the materials depends on numerous factors associated with the materials synthesis route and varies depending on the chemistry of the chosen alloying metal. Ideally, comparisons should be made versus standard reference materials using established standard experimental protocols (Noubactep et al. 2009), which once established, will significantly improve the design of future field applications.

\subsection{Limitations of the Nano-Fe ${ }^{0}$ Technology}

The efficiency of nano- $\mathrm{Fe}^{0}$ for aqueous contaminant reduction faces some key issues for in situ applica- 
tions in porous media. These challenges include: (1) the strong tendency of aggregation/agglomeration, (2) the rapid settlement on subsurface solid phases and (3) the porosity and permeability loss of porous media (Behrens et al. 2000; Dickinson and Scott 2010; Cullen et al. 2011; Mossa et al. 2011). Aggregation and settlement limit nano- $\mathrm{Fe}^{0}$ transport through porous media. Porosity and permeability loss limit nano- $\mathrm{Fe}^{0}$ transport to target contaminants. It was demonstrated that nano- $\mathrm{Fe}^{0}$ may travel only a few centimetres in porous media from the injection position under typical groundwater conditions (Tratnyek and Johnson 2006; Johnson et al. 2008; Comba et al. 2011; Gheju 2011). Accordingly, recent efforts have been made to (1) increase the porosity of porous media, (2) mechanically increase the distribution of nano- $\mathrm{Fe}^{0}$ and/or (3) chemically modify nano- $\mathrm{Fe}^{0}$ for improved aqueous mobility in porous networks.

\subsection{Improving the Efficiency of the Nano- $\mathrm{Fe}^{0}$ Systems}

\subsubsection{Dispersion Agents}

Methods to improve the aqueous mobility of nano- $\mathrm{Fe}^{0}$ have received the greatest research interest. It has been determined that the key to improving particle mobility is found in modifying their surface properties such that the nano- $\mathrm{Fe}^{0}$ have significantly improved colloidal stability and a commensurate reduction in the likelihood of adherence to mineral surfaces. Several synthetic methods are now available to produce more mobile nano-Fe ${ }^{0}$. Efficiently tested dispersants include anionic surface chargers (e.g. polyacrylic acid), non-ionic surfactants, starch and oil (Wu et al. 2009; Fang et al. 2011; Jiang et al. 2011; Mossa et al. 2011; Tong et al. 2011).

\subsubsection{Bimetallic Combinations}

In recent years, noble metals have been used to increase the reactivity of monometallic nano- $\mathrm{Fe}^{0}$ (Nagpal et al. 2010; Yuan et al. 2010; Zhu et al. 2010; Kadu et al. 2011; Mossa et al. 2011). As mentioned above, this appears counterintuitive as nano- $\mathrm{Fe}^{0}$ is already highly reactive due to its size (Wang and Zhang 1997; Zhang 2003; Macé et al. 2006; Ghauch et al. 2009) and is unstable during synthesis, storage and application (Jiang et al. 2011).
This chemical instability has been documented as a key reason for the observed lower efficiency exhibited by nano- $\mathrm{Fe}^{0}$ systems compared with $\mu \mathrm{m}$ - and $\mathrm{mm}-\mathrm{Fe}^{0}$ (Comba et al. 2011). Accordingly, it is questionable whether further enhancing the reactivity of nano- $\mathrm{Fe}^{0}$, e.g. by plating with more noble elements, may be of any benefit. The reactivity of nano- $\mathrm{Fe}^{0}$ will be discussed in the next section on the basis of mathematical modelling.

\section{Significance of Increased Reactivity}

\subsection{The Problem}

The increased $\mathrm{Fe}^{0}$ reactivity from $\mathrm{mm}$ to $\mathrm{nm}$ size should be better characterized. The relative reactivity of four different materials is discussed on the basis of $1 \mathrm{~kg} \mathrm{Fe}$ : $1 \mathrm{~nm}-\mathrm{Fe}^{0}\left(d_{0}=25 \mathrm{~nm}\right), 1 \mu \mathrm{m}-\mathrm{Fe}^{0}\left(d_{0}=\right.$ $25 \mu \mathrm{m})$ and $2 \mathrm{~mm}-\mathrm{Fe}^{0}\left(d_{0}=250\right.$ and $\left.1,000 \mu \mathrm{m}\right)$. Calculations for the number particles $(N)$ in $1 \mathrm{~kg}$ of each material and the number of layers $\left(N^{\prime}\right)$ in each particle are made after the Eqs. 1 and 2 presented in details elsewhere (Noubactep and Caré 2010a; Noubactep et al. 2010).

$N=\frac{M}{\rho_{\mathrm{Fe}} \cdot\left[4 / 3\left(\pi \cdot R_{0}^{3}\right)\right]}$

$N^{\prime}=2 \cdot\left[4 / 3\left(\pi R_{0}^{3}\right)\right] / a^{3}$

where $M$ is the mass of $\mathrm{Fe}^{0}$ (here $1 \mathrm{~kg}$ ), $\rho_{\mathrm{Fe}}$ is the specific weight of $\mathrm{Fe}\left(7,800 \mathrm{~kg} / \mathrm{m}^{3}\right), R_{0}$ is the initial radius of the Fe particle $\left(d=2 * R_{0}\right)$ and $a$ the lattice parameter $(a=2.866 \AA)$.

The results are summarized in Table 3 . It can be seen that the number of layers of $\mathrm{Fe}^{0}$ in individual particles varies from 87.2 for nano- $\mathrm{Fe}^{0}$ to more than $3 * 10^{6}$ for $\mathrm{mm}-\mathrm{Fe}^{0}(d=1 \mathrm{~mm})$. In the meantime, the number of particles in $1 \mathrm{~kg}$ decreased from $1.96 * 10^{18}$ for nano-Fe ${ }^{0}$ to only $3.1^{*} 10^{4}$ for $\mathrm{mm}-\mathrm{Fe}^{0}$. The ratio of the number of $\mathrm{Fe}^{0}$ layers in each particle to the number of $\mathrm{Fe}^{0}$ layers in nano- $\mathrm{Fe}^{0}$ varies from 1 to $4 * 10^{4}$. This ratio corresponds to the relative time $(\tau)$ as defined later (section 3.2). On the other hand, the ratio of the number of particles in $1 \mathrm{~kg}$ of nano- $\mathrm{Fe}^{0}$ to the number of particles in the same mass of each other materials varies from 1 to $6.4 * 10^{13}$. These results are 
Table 3 Summary of the values of the number of particles contained in $1 \mathrm{~kg}$ of each material, the number of layer making up each particle and estimation of the relative time $(\tau)$

\begin{tabular}{|c|c|c|c|c|c|c|}
\hline Size & $d(\mu \mathrm{m})$ & $n_{\text {particles }}(-)$ & $n_{\text {layers }}(-)$ & $n_{\text {layers }} / n_{\text {nano }}(-)$ & $n_{\text {nano }} / n_{\text {particles }}(-)$ & $\tau(-)$ \\
\hline Nano-Fe ${ }^{0}$ & $25 * 10^{-3}$ & $1.96 * 10^{18}$ & 87.2 & 1.0 & 1.0 & 1.0 \\
\hline$\mu \mathrm{m}-\mathrm{Fe}^{0}$ & 25 & $1.96^{*} 10^{9}$ & $87.2 * 10^{3}$ & $10^{3}$ & $10^{9}$ & $10^{3}$ \\
\hline $\mathrm{mm}-\mathrm{Fe}^{0}$ & 250 & $1.96 * 10^{6}$ & $87.2 * 10^{4}$ & $10^{4}$ & $10^{12}$ & $10^{4}$ \\
\hline $\mathrm{mm}-\mathrm{Fe}^{0}$ & 1,000 & $3.06 * 10^{4}$ & $3.49 * 10^{5}$ & $4 * 10^{4}$ & $6.4 * 10^{13}$ & $4 * 10^{4}$ \\
\hline
\end{tabular}

The life span of nano- $\mathrm{Fe}^{0}$ is operationally considered as the unit of time while assuming uniform corrosion. $\tau$ coincides with the ratio of the number of layers of $\mathrm{Fe}$ in each particle to that of nano- $\mathrm{Fe}^{0}$. The ratio of the number of particles in individual systems is also given

summarized in Fig. 1. Instead of the mass of $\mathrm{Fe}^{0}$, the number of electrons released by the conversion of $\mathrm{Fe}^{0}$ to $\mathrm{Fe}^{\mathrm{II}}$ is used to assess the kinetics of $\mathrm{Fe}^{0}$ consumption. This is discussed in the next section.

\subsection{Relative Corrosion Kinetics of $\mathrm{Fe}^{0}$ Materials}

For the discussion in this section, uniform corrosion for spherical particles is assumed. Individual particles corrode independently until material depletion. It is further assumed for simplicity that individual layers corrode with the same kinetics independent of particle size. The latter assumption is conservative as larger particles react slower than smaller (Macé et al. 2006; Reardon et al. 2008; Nagpal et al. 2010). With these assumptions, a relative time $(\tau)$ can be defined while taking the time for the corrosion of the smallest

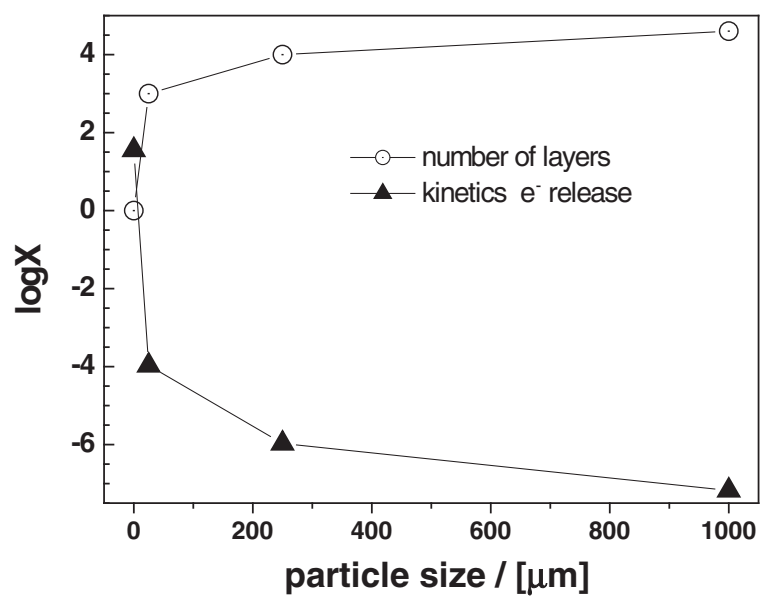

Fig. 1 Comparison of the evolution of the kinetics of electron release and the number of layers in each $\mathrm{Fe}^{0}$ particle as a function of the particle size. It is shown that smaller particles release huge amounts of electrons within a very short time. Calculations are made for $1 \mathrm{~kg}$ of $\mathrm{Fe}^{0}$ material particle (here 87.2 layers of nano-Fe ${ }^{0}$ ) or $t_{\infty}$, nano as unit.

$\tau=t / t_{\infty, \text { nano }}$

Accordingly, one unit of time corresponds to the time to nano- $\mathrm{Fe}^{0}$ depletion. Remember that all $1.96 * 10^{18}$ particles in the $1 \mathrm{~kg}$ of nano- $\mathrm{Fe}^{0}$ simultaneously corrode with the same kinetics. The results of the calculations are presented in Fig. 2. From Fig. 2a and Table 3, it can be seen that after nano-Fe ${ }^{0}$ depletion, the material with $1,000-\mu \mathrm{m}$ (or $1 \mathrm{~mm}$ ) diameter will still react for more than $3 * 10^{4}$ times longer than the time necessary for nano- $\mathrm{Fe}^{0}$ depletion $\left(\tau=4 * 10^{4}\right.$, see Table 3 ). Figure $2 \mathrm{~b}$ shows that the $\mathrm{mm}-\mathrm{Fe}^{0}$ with $250-\mu \mathrm{m}$ diameter is depleted after about $10^{4} * t_{\infty}$, nano.

Based on the assumptions above, the service life of a nano-Fe ${ }^{0}$ particle can be estimated. Table 4 summarizes the results of such estimations while varying the service life of a $1 \mathrm{~mm} \mathrm{Fe}{ }^{0}$ particle from 5 to 40 years. This assumption is based on the fact that conventional $\mathrm{Fe}^{0}$ walls are supposed to function for several decades (here up to 4 decades). Results show (Table 4 ) that the maximum life span of a nano- $\mathrm{Fe}^{0}$ is about $8.8 \mathrm{~h}$ (less than 1 day). In other words, following approximately $9 \mathrm{~h}$ from subsurface deployment it is suggested that all nano- $\mathrm{Fe}^{0}$ would be reactively exhausted. The success of this is dependent on three key factors: (1) the hydrodynamic conditions: pore size, porosity, flow velocity and degree of mixing or turbulence, (2) the water chemistry and the affinity of nano- $\mathrm{Fe}^{0}$ and its transformation products to the soil materials and (3) the reactivity of $\mathrm{Fe}^{0}$.

It is certain that the dynamic process of transformation of concentric layers of $\mathrm{Fe}^{0}$ atoms to concentric layers of iron (hydr)oxides cannot be linear (Noubactep 
(a)

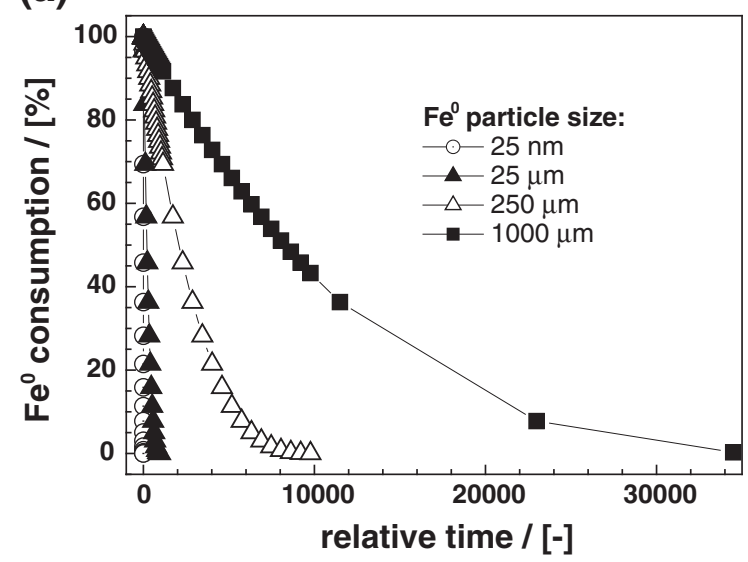

(b)

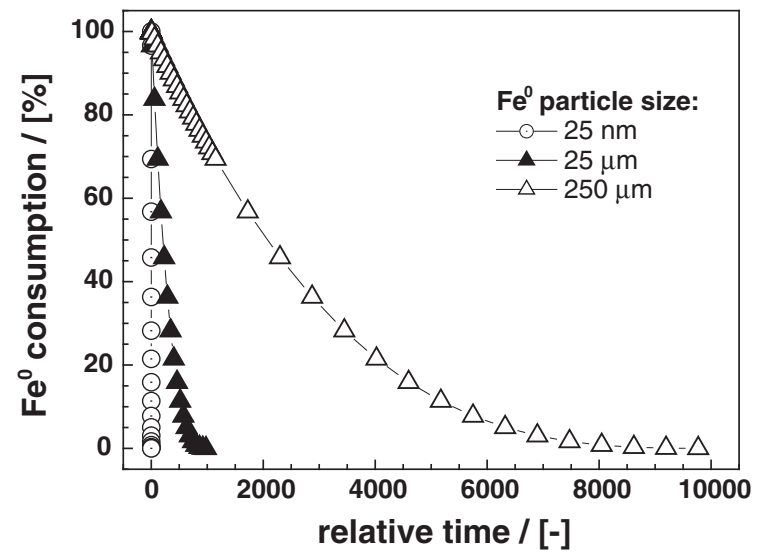

Fig. 2 Kinetics of the process of $\mathrm{Fe}^{0}$ exhaustion at nano-, micro- and millimetre scale as for: $\mathbf{a} d \leq 1,000 \mu \mathrm{m}$ and $\mathbf{b} d \leq$ $200 \mu \mathrm{m}$

and Caré 2010b). In fact, effects similar to "case hardening" for food and wood drying will lead to "surface hardened layers" (Tarvainen et al. 2006; Fernando et al. 2008) leading to differential kinetics/ extents of $\mathrm{Fe}^{0}$ passivation for different particle size ranges. In other words, the extent of restricted corrosion rates through resulting surface hardened layers will be different for $\mathrm{nm}-, \mu \mathrm{m}$ - and $\mathrm{mm}-\mathrm{Fe}^{0}$. Bearing this in mind, the very short relative life span of a nano- $\mathrm{Fe}^{0}$ estimated above will be used for the discussion in this work. It is certain that "casehardening"-like effects will prolong this hypothetical life span to some days or weeks.

\subsection{Extent of Iron Corrosion from $\mathrm{Fe}^{0}$ Materials}

A discussion as to the extent of $\mathrm{Fe}^{0}$ consumption is limited in the present section to $\tau=1$ or $\boldsymbol{t}_{\infty \text {, nano. It is }}$ considered for simplification that the sole iron corrosion product is $\mathrm{Fe}_{3} \mathrm{O}_{4}$. The corresponding coefficient of volumetric expansion is $\boldsymbol{\eta}_{\mathrm{Fe} 3 \mathrm{O} 4}=2.08$ (Eq. 4) (Caré et al. 2008). Using $\rho=M / V$, the volume of $\mathrm{Fe}$ corresponding to $1 \mathrm{~kg} \mathrm{Fe}{ }^{0}$ is calculated as $127.0 \mathrm{~mL}\left(V_{0}\right)$. This is the initial volume of $\mathrm{Fe}^{0}\left(V_{0}\right)$. Following corrosion, this volume is partly or totally consumed. The volume $(\Delta V)$ corresponding to the volume of pores occupied by the volumetric expansion of corrosion products can be estimated.

Assuming that the coefficient of volumetric expansion $(\eta)$ ("rust expansion coefficient" or "specific volume") (Anstice et al. 1993; Caré et al. 2008; Zhao et al. 2011) of the reaction products is:

$\eta=V_{\text {oxide }} / V_{\mathrm{Fe}}$

where $V_{\text {oxide }}$ is the volume of the reaction product and $V_{\mathrm{Fe}}$ the volume of the parent $\mathrm{Fe}^{0}$.

The volume $\Delta V$ characterizing the extent of porosity loss due to volumetric expansion is given by Eq. 5 :

$$
\begin{aligned}
& \Delta V=(\eta-1)^{*} V_{\text {consumed Fe }} \\
& \Delta V=V_{\infty}-V_{0}=v^{*}\left(\eta_{\mathrm{Fe} 3 \mathrm{O} 4}-1\right)^{*} V_{0}
\end{aligned}
$$

Where $V_{\text {consumed } \mathrm{Fe}}$ is the volume of consumed $\mathrm{Fe}^{0}$ at time $t_{\infty}, V_{0}$ is the volume occupied by the initial $\mathrm{Fe}^{0}$ particles and $\nu(\nu \leq 1)$ is the fraction of the initial

Table 4 Estimation of the value of the life span $\left(t_{\infty}\right)$ of a nano- $\mathrm{Fe}^{0}$ particle with $25 \mathrm{~nm}$ diameter for barrier life spans $(t)$ from 10 to

\begin{tabular}{|c|c|c|c|c|c|c|c|c|}
\hline$t$ (years) & 5 & 10 & 15 & 20 & 25 & 30 & 35 & 40 \\
\hline$t_{\mu \mathrm{m}}$ (days) & 45.7 & 91.3 & 137.0 & 182.6 & 228.3 & 273.9 & 319.6 & 365.3 \\
\hline$t_{\mu \mathrm{m}}$ (years) & 0.2 & 0.3 & 0.5 & 0.7 & 0.9 & 1.0 & 1.2 & 1.4 \\
\hline$t_{\infty}$ (hours) & 1.1 & 2.2 & 3.3 & 4.4 & 5.5 & 6.6 & 7.7 & 8.8 \\
\hline
\end{tabular}
40 years

The considered conventional reactive wall contains granular $\mathrm{Fe}^{0}$ with a diameter of $1 \mathrm{~mm}$. For comparison, the relative life span (in days and years) of the micrometric particles is given 
amount of $\mathrm{Fe}^{0}(1 \mathrm{~kg})$ which has reacted at $t_{\infty}$, nano. $V_{\infty}$ is the total volume occupied by residual $\mathrm{Fe}^{0}$ and in situ formed corrosion products. $t_{\infty}$ corresponds to nano- $\mathrm{Fe}^{0}$ depletion $(25 \mathrm{~nm}$ in this section). In the discussion on the reactivity at nanoscale, $t_{\infty}$ corresponds to the depletion of the material with $10-\mathrm{nm}$ diameter (Section 4).

$V_{\infty}=\eta^{*} V_{\text {consumed Fe }}+\left(V_{0}-V_{\text {consumed Fe }}\right)$

$V_{\infty}=V_{0} *\left[1+v^{*}\left(\eta_{\mathrm{Fe} 3 \mathrm{O} 4}-1\right)\right]$

The volumetric expansion ( $\Delta V$, Eq. 5) can be characterized as percent of the initial volume $\left(V_{0}\right)$ using Eq. 7:

$\Delta V(\%)=100 * v^{*}\left(\eta_{\mathrm{Fe} 3 \mathrm{O} 4}-1\right)$

Table 5 summarizes the results. It is shown that at $\tau=1$ (nano- $\mathrm{Fe}^{0}$ depletion), a volume augmentation of $108 \%$ has occurred in the nano- $\mathrm{Fe}^{0}$ system, with volume augmentations in all other systems lower than $0.5 \%$. This clearly shows that the porosity of the subsurface will be significantly influenced by nano$\mathrm{Fe}^{0}$ at $t_{\infty}$. Remember that $100 \%$ reactive exhaustion of nano- $\mathrm{Fe}^{0}$ is predicted to occur by approximately $9 \mathrm{~h}$ time. During this same period the porosity loss due to expansive iron corrosion is likely to be negligible for all other $\mathrm{Fe}^{0}$ particle size fractions. Calculations for Akageneite $\beta-\mathrm{FeOOH}\left(\eta_{\mathrm{FeOOH}}=3.48\right)$ as sole corrosion products shows that $V_{\infty, \text { nano }}=448.7 \mathrm{~mL}, \Delta V=$ $320.5 \mathrm{~mL}$ or $250.4 \%$. The examples of $\mathrm{Fe}_{3} \mathrm{O}_{4}$ (anoxic) and $\mathrm{FeOOH}$ (oxic) demonstrate the crucial importance of the nature of formed corrosion products for the discussion of the extent of porosity loss.
Another important aspect of $\mathrm{Fe}^{0}$ consumption is given by the number of moles of $\mathrm{Fe}^{0}$ that have been oxidized (Table 5). Assuming contaminant reduction, Table 5 shows that after $\tau=1,35.71$ moles of electrons have been released in the nano- $\mathrm{Fe}^{0}$ system but less than 0.11 moles in all other systems. In other words, up to 35.71 moles of electrons are available for contaminant reduction per $\mathrm{kg}$ nano- $\mathrm{Fe}^{0}$ within a few hours of reaction $(<9 \mathrm{~h})$. But what proportion of the electrons produced would reach the contaminant within this period? That is the major question to be answered for the further development of the nano- $\mathrm{Fe}^{0}$ technology for in situ applications.

\section{Reactivity of Nano-Fe ${ }^{0}$ Materials}

The presentation until now has discussed the reactivity of nano- $\mathrm{Fe}^{0}$ in comparison to larger scale $\mathrm{Fe}^{0}$. Section 4 will focus only on the nanoscale size fraction $(d \leq 100 \mathrm{~nm})$. Equations $1-7$ will be used and the particle size will vary from 10 to $100 \mathrm{~nm}$. As stated above $\boldsymbol{t}_{\infty}$ is for a nano- $\mathrm{Fe}^{0}$ of $10 \mathrm{~nm}$ in diameter and the reaction proceeding until $100 \%$ reactive exhaustion has been achieved.

\section{1 $\mathrm{Fe}^{0}$ Reactivity at Nanoscale}

Table 6 summarizes the results of calculations for the number of $\mathrm{Fe}^{0}$ particles and number of layers of $\mathrm{Fe}^{0}$ in each nano- $\mathrm{Fe}^{0}$. It is shown that $1 \mathrm{~kg}$ of the material with $d=10 \mathrm{~nm}$ contains 1,000 times more particles than a material of $d=100 \mathrm{~nm}$.

Table 5 Estimation of the extent of porosity loss $(\Delta V)$ due to the volumetric expansion of iron corrosion for $\mathrm{Fe}^{0}$ particles of different sizes

\begin{tabular}{llrrrrrrrr}
\hline Size & $m_{\text {consumed }}(\mathrm{kg})$ & $\nu(\%)$ & $V_{\infty}(\mathrm{mL})$ & $\Delta V(\mathrm{~mL})$ & $\Delta V(\%)$ & $n_{\mathrm{Fe}(\mathrm{II})}(\mathrm{moles})$ & $n_{\mathrm{Fe} 3 \mathrm{O} 4}(\mathrm{moles})$ & $n_{\text {electrons }}(\mathrm{moles})$ & $n_{\text {nano }} / n_{\text {electrons }}(-)$ \\
\hline $\mathrm{nm}_{-\mathrm{Fe}}{ }^{0}$ & $10^{0}$ & 100.00 & 264.16 & 137.16 & 108.00 & 17.857 & 5.9524 & 35.714 & 1 \\
$\mu \mathrm{m}-\mathrm{Fe}^{0}$ & $3 * 10^{-3}$ & 0.30 & 127.41 & 0.41 & 0.32 & 0.053 & 0.0178 & 0.107 & 335 \\
$\mathrm{~mm}-\mathrm{Fe}^{0}$ & $3 * 10^{-4}$ & 0.03 & 127.04 & 0.04 & 0.03 & 0.005 & 0.0018 & 0.011 & 3,342 \\
$\mathrm{~mm}-\mathrm{Fe}^{0}$ & $7.5^{*} 10^{-5}$ & 0.01 & 127.01 & 0.01 & 0.01 & 0.001 & 0.0004 & 0.003 & 13,369 \\
\hline
\end{tabular}

The operational unit of time is arbitrarily the time to nano- $\mathrm{Fe}^{0}$ depletion $\left(t_{\infty}\right)$

$V_{0}$ volume occupied by the initial $\mathrm{Fe}^{0}$ particles, $V_{\infty}$ volume occupied by residual $\mathrm{Fe}^{0}$ and in situ formed corrosion products. $\Delta V$ volume of pore occupied by the volumetric expansion of corrosion products, $m_{\text {consumed }}$ mass of $\mathrm{Fe}^{0}$ consumed, $\nu$ percent of $\mathrm{Fe}^{0}$ depletion, $n_{\mathrm{Fe}(\mathrm{II})}$ number of moles of corroded $\mathrm{Fe}^{0}, n_{\mathrm{Fe} 3 \mathrm{O} 4}$ number of moles of generated iron corrosion products, $n_{\text {electrons }}=2^{*} n_{\mathrm{Fe}(\mathrm{II})}$ number of electrons released by corroded iron, $n_{\text {nano }} / n_{\text {electrons }}$ the ratio of the number of electrons produced in by nano-Fe ${ }^{0}$ to $n_{\mathrm{electrons}}$ 
Table 6 Summary of the values of the number of particles contained in $1 \mathrm{~kg}$ of each nano-Fe ${ }^{0}$, the number of layer making up each particle and estimation of the relative time $(\tau)$

\begin{tabular}{llllll}
\hline$d(\mathrm{~nm})$ & $n_{\text {particles }}(-)$ & $n_{\text {layers }}(-)$ & $n_{\text {layers }} / n_{10}(-)$ & $n_{10} / n_{\text {particles }}(-)$ & $\tau(-)$ \\
\hline 10 & $3.06 * 10^{19}$ & 34.9 & 1.0 & 1.0 & 1.0 \\
25 & $1.96 * 10^{18}$ & 87.2 & 2.5 & 16 & 2.5 \\
50 & $2.45 * 10^{11}$ & 174.5 & 5.0 & 125 & 5.0 \\
75 & $7.25 * 10^{16}$ & 261.7 & 7.5 & 422 & 7.5 \\
100 & $3.06 * 10^{16}$ & 348.9 & 10.0 & 1,000 & 10.0 \\
\hline
\end{tabular}

The life span of the material with the smallest particle site $(d=10 \mathrm{~nm})$ is operationally considered as the unit of time while assuming uniform corrosion. The ratio of the number of particles in $1 \mathrm{~kg}$ of $d=10 \mathrm{~nm}$ to that of other $d$ values is also given

Table 6 also shows that the maximum value of the relative time $(\tau)$ is 10 (or $10^{1}$ ). This is more practical for graphical representations than situations where nano- $\mathrm{Fe}^{0}$ are compared with larger particles $\left(t \leq 10^{4}\right)$. The physical significance of $\tau$ is more important, it means that if a nano- $\mathrm{Fe}^{0}$ with a diameter of $10 \mathrm{~nm}$ depletes after 2 days, the material with a diameter $100 \mathrm{~nm}$ will deplete after 20 days. For field applications, the selection of the particle size to be used should be dictated by site specific characteristics. Which diameter could quantitatively reach the contaminants before depletion? And what fraction of the material will have already oxidized on the path? What is the impact of this oxidation on the transport of nano- $\mathrm{Fe}^{0}$ in the porous aquifer? These are some key questions to be answered in order to give this possibly very efficient technology a scientific basis.

Figure 3 summarizes the evolution of the volumetric expansion in all five nano- $\mathrm{Fe}^{0}$ systems. It can be seen from Fig. 3a that the smallest material $(d=10 \mathrm{~nm})$ experiences the $108 \%$ volumetric expansion within a short time $(\tau=1)$ while the larger materials $(d=$ $100 \mathrm{~nm}$ ) needs ten more time for the same expansion. Accordingly, beside the question whether the material will reach the contaminant under site specific conditions, the question has to be answered how the volumetric expansion will impact the aquifer porosity (and permeability).

Figure $3 b$ compares the variation of the volumetric expansion for two different iron corrosion products, $\mathrm{Fe}_{3} \mathrm{O}_{4}$ and $\mathrm{FeOOH}$, which are considered the most likely products in anoxic and oxic aquifers respectively. It also shows that when designing a nano- $\mathrm{Fe}^{0}$ injection strategy, however, the availability of oxidiz- (a)

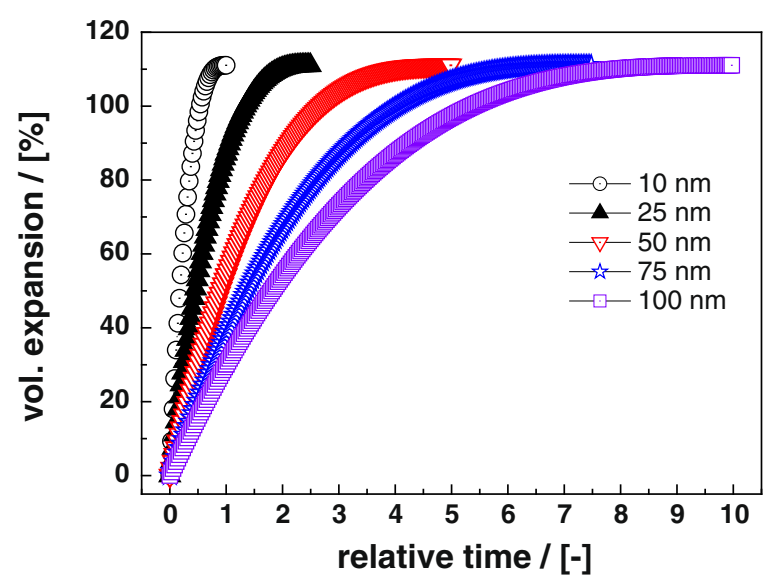

(b)

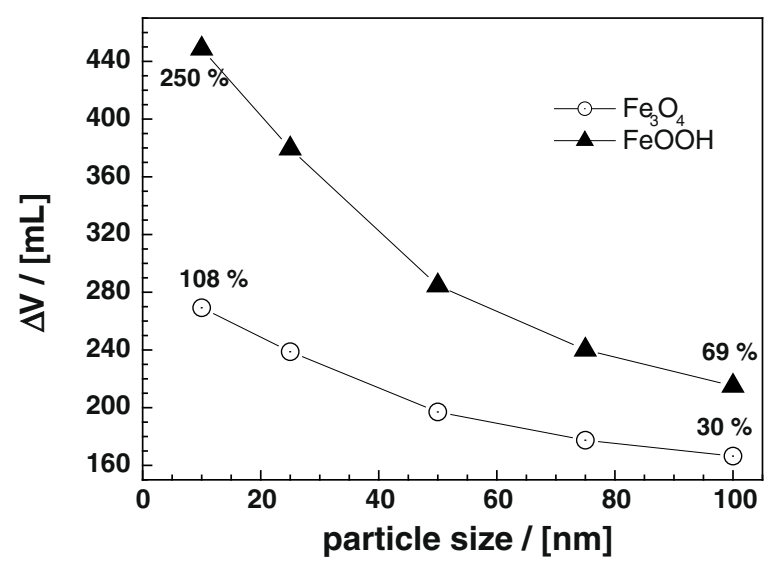

Fig. 3 Kinetics of the process of porosity loss at nanoscale as characterized by: a the percent volumetric expansion for the five considered particle sizes, and $\mathbf{b}$ the absolute value of $\Delta V$ $(\mathrm{mL})$ at $\tau=1$ for two different iron corrosion products $\left(\mathrm{Fe}_{3} \mathrm{O}_{4}\right.$ and $\mathrm{FeOOH}$ ) 
ing species (e.g. $\mathrm{MnO}_{2}$ and $\mathrm{O}_{2}$ ) must also to be taken into account. Figure $3 \mathrm{a}$ shows that under both conditions the trend of porosity loss is similar but the extent is proportional to the coefficient of volumetric expansion $(\eta)$. In particular, at $\tau=1$, the system with the material $d=10 \mathrm{~nm}$ experiences $250 \%$ volumetric expansion under oxic conditions and only $110 \%$ under anoxic conditions. As a result the kinetics of more rapid $\mathrm{Fe}^{0}$ corrosion in an oxygenrich environment must also be considered for an effective treatment strategy.

\section{2 $\mathrm{Fe}^{0}$ Reactivity of Nano-bimetallics}

The reactivity of monometallic nano- $\mathrm{Fe}^{0}$ can be improved by combining it with a noble metal. Assuming $\alpha(\alpha>1)$ the coefficient of reactivity enhancement, the relation between the relative time of a bimetallic system $\left(\tau_{\mathrm{Fe} / \mathrm{M}}\right)$ and that of a non-plated metal $\left(\tau_{\mathrm{Fe}}\right)$ is given by Eq. 6 :

$\tau_{\mathrm{Fe}}=\alpha^{*} \tau_{\mathrm{Fe} / M}$

To characterize the impact of plating on nano- $\mathrm{Fe}^{0}$, the material with the largest size $(d=100 \mathrm{~nm})$ will be plated by three hypothetical metals $\left(M_{1}{ }^{0}, M_{2}{ }^{0}\right.$ and $M_{3}{ }^{0}$ ) to yield a reactivity factor of 2.5 (for $\mathrm{Fe}^{0} / M_{1}{ }^{0}$ ), 5 (for $\mathrm{Fe}^{0} / M_{2}{ }^{0}$ ) and 10 (for $\mathrm{Fe}^{0} / M_{3}{ }^{0}$ ). The considered $\alpha$ values of $(\alpha \leq 10)$ are realistic and even conservative. In fact, reported reactivity enhancement is essentially larger (Chen et al. 2011; Zhuang et al. 2011). For example, Zhuang et al. (2011) reported that palladized nano- $\mathrm{Fe}^{0}$ promoted the dehalogenation kinetics for polybrominated diphenyl ethers by orders of magnitude equal to 2, 3 and $4(\alpha \geq 100)$. The results of the calculations for the four systems $(d=10 \mathrm{~nm})$ are summarized in Fig. 4. The system with $d=10 \mathrm{~nm}$ is represented for comparison. It can be seen that system $\mathrm{Fe}^{0} / M_{3}{ }^{0}(d=100 \mathrm{~nm})$ is as reactive as $\mathrm{Fe}^{0}(d=10 \mathrm{~nm})$. Given that the reactivity of nano- $\mathrm{Fe}^{0}(d=100 \mathrm{~nm})$ could already significantly been too high in some situations, the results from Fig. 4 strongly question the suitability of plating at nanoscale. Accordingly, while the application of bimetallic $\mathrm{Fe}^{0}$ is definitively useful at $\mu \mathrm{m}$ and $\mathrm{mm}$ scale, it usefulness at nanoscale is likely inappropriate. It can also be noted that by increasing the reactivity of the material the rate at which volumetric pore clogging also increases. As a consequence it should be acknowledged that there

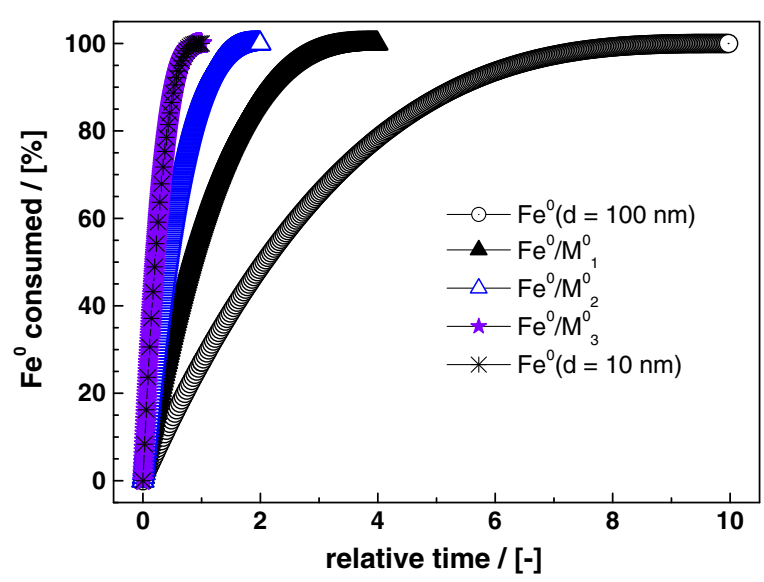

Fig. 4 Calculated extent of $\mathrm{Fe}^{0}$ exhaustion as a function of the relative time $(\tau)$ for three ideal bimetallic systems based on the material with $100 \mathrm{~nm}$ diameter. The material with $10 \mathrm{~nm}$ diameter is represented for comparison

exists a conceptual play-off between increased reaction rate and increased porosity loss, the impact of which will vary depending on the physiochemical conditions of each contaminated site.

\subsection{Characterizing the Process of Reactivity Loss}

To better characterize the process of porosity loss due to the volumetric expansion of nano- $\mathrm{Fe}^{0}$, the evolution of the porosity of a sand column filled with nano$\mathrm{Fe}^{0}$ will be discussed as volumetric expansion proceeds. A laboratory column with a height $\mathrm{h}(h=$ $75.0 \mathrm{~cm})$ and diameter $D(D=5.0 \mathrm{~cm})$ is composed of spherical sand particles $(d=5.0 \mathrm{~mm})$. The compactness of the column is ideally $C=0.64$ (Noubactep and Caré 2010a, Noubactep et al. 2010). The pore volume is given by Eq. 9:

$V_{\text {pore }}=V^{*}(1-C)$

where $V$ is the apparent volume of the sand column ( $V=$ $\left.h^{*} \pi^{*} D^{2} / 4\right)$.

It is supposed that the nano- $\mathrm{Fe}^{0}$ particles fill the inter-granular porosity of the sand column $V_{\text {pore }}$ without modifying the compactness $C$ and the apparent volume $V$ of the sand column. The residual porosity of the sand column $\left(V_{\text {pore }}^{\prime}\right)$ is given by Eq. 10 :

$V_{\text {pore }}^{\prime}=V^{*}(1-C)-V_{0}$

where $V_{0}$ is the volume of the Fe particles.

The evolution of the residual porosity $\left(V_{\text {pore }}^{\prime}\right)$ as nano- $\mathrm{Fe}^{0}$ particles undergo volumetric expansive cor- 
rosion is considered by introducing the specific volume $(\eta)$ of the reaction products according to Eq. 11:

$$
V_{\text {pore }}^{\prime}=V^{*}(1-C)-\left(V_{0}-V_{\text {consumed Fe }}\right)-\eta^{*} V_{\text {consumed Fe }}
$$

$$
V_{\text {pore }}^{\prime}=V^{*}(1-C)-V_{0}-(\eta-1)^{*} V_{\text {consumed Fe }}
$$

where $V_{\text {consumed Fe }}$ is the volume of nano- $\mathrm{Fe}^{0}$ particles which is consumed at a given time.

Equations 9 through 11 are very useful to design reactive zone. However, they are limited to describe the initial $\left(V_{\text {pore }}\right)$ and a final conditions ( $\left.V_{\text {pore }}^{\prime}\right)$ regardless on the nature of iron corrosion products and the kinetics of the process.

Using a sand column comparable to one of those used by Moraci and Calabrò (2010) and $1 \mathrm{~kg}$ of nano$\mathrm{Fe}^{0}$, the process of pore filling (porosity loss) can be better characterized. For simplicity, nano- $\mathrm{Fe}^{0}$ considered as transported by a biodegradable dispersant which does not significantly contribute to porosity loss. As shown in Section 3.3, $1 \mathrm{~kg}$ of nano- $\mathrm{Fe}^{0}$ occupies a volume of $127 \mathrm{~mL}$. The initial pore volume of the sand column calculated after Eq. 9 is $530.36 \mathrm{~mL}(100 \%$ porosity), i.e. a capacity for approximately $4.17 \mathrm{~kg}$ of nano-Fe ${ }^{0}$. Filling the initial pore volume of the sand column $(530.36 \mathrm{~mL})$ with $1 \mathrm{~kg}$ of nano- $\mathrm{Fe}^{0}(127.00 \mathrm{~mL})$ yields a $23.9 \%$ porosity loss (Table 7). This, however, does not take into account the expansive nature of iron during oxidative corrosion.

Using the eight possible iron corrosion products documented by Caré et al. (2008) and their respective coefficient of volumetric expansion $(2.08 \leq \eta \leq 6.40)$, the extent of porosity loss is calculated and summarized in Table 7 . The results show that the residual volume of pores $\left(V_{\text {pore }}^{\prime}\right)$ decreases with increasing $\eta$ values and is zero for $\mathrm{Fe}(\mathrm{OH})_{3}$ and $\mathrm{Fe}(\mathrm{OH})_{3} 3 \mathrm{H}_{2} \mathrm{O}$ $\left(100 \%\right.$ porosity loss). Ferrihydrite $\left(\mathrm{Fe}(\mathrm{OH})_{3} 3 \mathrm{H}_{2} \mathrm{O}\right)$ is the largest known iron corrosion products. In other words, depending on environmental conditions as little as $1 \mathrm{~kg}$ of nano- $\mathrm{Fe}^{0}$ could clog the tested column. Although this discussion considers the nature of the corrosion products, there are other important factors which must be considered. The negative values $(-3.04$ and $-282.4 \mathrm{~mL})$ corresponds to the mass of $\mathrm{Fe}^{0}$ which will not oxidized because of lack of space for expansion (Noubactep and Caré 2010a; Noubactep et al. 2010).

The extent of porosity loss ( $\Delta V$ in $\%$ ) given in Table 7 assumes uniform distribution of nano- $\mathrm{Fe}^{0}$ in the whole column. This is, however, not a very good field representation. For example, if $1 \mathrm{~kg}$ of nano- $\mathrm{Fe}^{0}$ $\left(V_{0}=127 \mathrm{~mL}\right)$ is uniformly distributed only in the first third of the column $\left(V_{\text {pore }}^{1 / 3}=176.8 \mathrm{~mL}\right)$, with $\mathrm{Fe}_{3} \mathrm{O}_{4}$ as the primary corrosion product $(\Delta V=137.16 \mathrm{~mL})$ a $78 \%$ porosity loss can be expected. For all other oxide phases it is calculated that complete porosity loss $(100 \%)$ will precede nano- $\mathrm{Fe}^{0}$ reactive exhaustion. However, in the practice a system with $78 \%$ porosity

\begin{tabular}{|c|c|c|c|c|c|}
\hline Fe species & $\eta(-)$ & $V_{\infty}(\mathrm{mL})$ & $\Delta V(\mathrm{~mL})$ & $V_{\text {pore }}^{\prime}(\mathrm{mL})$ & $\Delta V_{\text {pore }}(\%)$ \\
\hline $\mathrm{Fe}^{0}$ & 1 & 127 & 0 & 403.4 & 23.9 \\
\hline $\mathrm{Fe}_{3} \mathrm{O}_{4}$ & 2.08 & 264.2 & 137.2 & 266.2 & 49.8 \\
\hline $\mathrm{Fe}_{2} \mathrm{O}_{3}$ & 2.12 & 269.2 & 142.3 & 261.1 & 50.8 \\
\hline$\alpha-\mathrm{FeOOH}$ & 2.91 & 369.6 & 242.6 & 160.8 & 69.7 \\
\hline$\gamma$-FeOOH & 3.03 & 384.8 & 258.0 & 145.6 & 72.6 \\
\hline$\beta-\mathrm{FeOOH}$ & 3.48 & 442.0 & 315.0 & 88.4 & 83.3 \\
\hline $\mathrm{Fe}(\mathrm{OH})_{2}$ & 3.75 & 476.3 & 349.3 & 54.1 & 89.8 \\
\hline $\mathrm{Fe}(\mathrm{OH})_{3}$ & 4.2 & 533.4 & 406.4 & -3.0 & 100.0 \\
\hline $\mathrm{Fe}(\mathrm{OH})_{3} 3 \mathrm{H}_{2} \mathrm{O}$ & 6.4 & 812.8 & 685.8 & -282.4 & 100.0 \\
\hline
\end{tabular}

Table 7 Summary of the extent of porosity loss $\left(\Delta V_{\text {pore }}\right.$ in $\left.\%\right)$ as $1 \mathrm{~kg}$ of nano- $\mathrm{Fe}^{0}\left(V_{0}=127 \mathrm{~mL}\right)$ is corroded to various iron oxides

$V_{\infty}$ is the volume of iron oxide at $\mathrm{Fe}^{0}$ exhaustion. The initial volume of pore $\left(V_{\text {pore }}\right)$ is $530.4 \mathrm{~mL}$ and $V_{\text {pore }}^{\prime}$ is the residual pore volume at $\mathrm{Fe}^{0}$ exhaustion. The absolute value of negative values for $V_{\text {pore }}^{\prime}$ corresponds to the mass of nano-Fe ${ }^{0}$ which cannot oxidize because of lack of space for volumetric expansion 
loss is considered as clogged. One possibility to avoid the clogging of the entrance zone of a porous system is to intermittently inject calculated amounts of nano$\mathrm{Fe}^{0}$. The volume to be injected at each event and the time scale between two injections are necessarily determined by site specific characteristics (e.g. porosity of the aquifer and water flow rate).

\section{Discussion}

A primary reason behind the interest into the use of nano- $\mathrm{Fe}^{0}$ particles over $\mu \mathrm{m}-\mathrm{Fe}^{0}$ and $\mathrm{mm}-\mathrm{Fe}^{0}$ particles for water treatment is ascribed to a significant increase the materials efficiency (Comba et al. 2011; Gheju 2011). For example, as reported by Vodyanitskii (2010), Kanel et al. (2006) reported near-total remediation of a $1 \mathrm{mg} \mathrm{L}^{-1} \mathrm{As}^{\mathrm{V}}$ solution within only $10 \mathrm{~min}$ by a nano- $\mathrm{Fe}^{0}$ with a specific surface of $24 \mathrm{~m}^{2} / \mathrm{g}$, whereas the same goal was achieved by $\mathrm{mm}-\mathrm{Fe}^{0}\left(1-2 \mathrm{~m}^{2} / \mathrm{g}\right)$ after only 4 days or $5,760 \mathrm{~min}$ (ratio of time, 570; average ratio of surface, 16). However, this experimental evidence is highly qualitative as neither the number of atoms directly accessible at the surface nor the intrinsic reactivity of individual materials are considered in both cases (Noubactep and Caré 2010b). For a better comparative result, the following three key conditions must be considered: (1) the intrinsic $\mathrm{Fe}^{0}$ reactivity should be characterized, (2) the amount of used materials should be based on the reaction stoichiometry and (3) the experimental conditions should be relevant for field applications. In particular, the driving force for the transport of contaminants and $\mathrm{Fe}$ species should be relevant for field situations: (1) mixing operation (type and intensity) in batch studies and (2) flow rate and column dimensions in column studies (Noubactep et al. 2009).

\subsection{Transport of Nano- $\mathrm{Fe}^{0}$ to the Contaminants}

The efficiency of nano- $\mathrm{Fe}^{0}$ for the in situ treatment of a contaminated aquifer body is intrinsically linked to the extent of physical contact between $\mathrm{Fe}^{0}$ and any aqueous contaminant species present. In some circumstances, contaminants could diffuse to the suspended $\mathrm{Fe}^{0}$ particles and be degraded in the aqueous phase. However, typically the suspended $\mathrm{Fe}^{0}$ particles must migrate to the contaminants. $\mathrm{As}^{\mathrm{Fe}}{ }^{0}$ particles are transported from the injection zone to the target contaminant plume by natural groundwater, diffusion experiments under relevant groundwater velocity, using site specific aquifer materials are essential in order to effectively assess the suitability of nano- $\mathrm{Fe}^{0}$ for in situ applications (Antia 2011).

Contaminants are typically partitioned between sediment and water phases in a "pseudo-equilibrium" state. Therefore, it is likely that $\mathrm{Fe}^{0}$ particles whilst acting to reduce any soluble contaminants are also likely to promote the dissolution of a range of adsorbed chemical species (Le Chatelier's principle). However, as water is also a redox-amenable species the specific mechanism for nano- $\mathrm{Fe}^{0}$ reactivity in a range of conditions is difficult to resolve (Tratnyek and Johnson 2006). In other words, nano- $\mathrm{Fe}^{0}$ is readily oxidized by $\mathrm{H}_{2} \mathrm{O}$ during subsurface migration to the target contaminant plume and also competes with any other redox-amenable (including contaminants) present in the groundwater. Additionally, expansive iron corrosion will yield voluminous iron (hydr)oxides (Table 7) with limited aqueous mobility due to (1) an increased size and weight and (2) a possible increased affinity to aquifer material.

This discussion has intentionally neglected the segregation between parent compounds, the reaction products and their relative affinity to $\mathrm{Fe}^{0}$ and $\mathrm{Fe}$ (hydro)oxides. The fact that the core $\mathrm{Fe}^{0}$ is always covered by oxide layers is also neglected for simplification. The process of preferential flow which is crucial in predicting mass transfer in the subsurface is also not considered (Flury and Flühler 1994; Fryar and Schwartz 1998; Simunek et al. 2003; Clothier et al. 2008; Allaire et al. 2009). However, it is clearly shown, that due the acute redox sensitivity of nano$\mathrm{Fe}^{0}$ and the subsequent significant formation of highly voluminous oxidative corrosion products it is likely that for environmentally relevant distances (metre), a significant proportion of the originally injected nano- $\mathrm{Fe}^{0}$ will remain "clogged" in pore spaces.

Beside the transport of nano- $\mathrm{Fe}^{0}$ to contaminants, the possibility of quantitative contaminant desorption and their subsequent transformation by suspended $\mathrm{Fe}^{0}$ could be considered. However, it is not likely that concentration-gradient-driven mass transfer could be quantitative at considered distances (metre). It should be recalled that the slow kinetics of contaminant desorption form aquifer materials is 
the major cause of the ineffectiveness of the pumpand-treat technology for groundwater remediation (McMurty and Elton 1985; Mackay and Cherry 1989; Starr and Cherry 1994).

This section has shown that it is likely that the success of nano- $\mathrm{Fe}^{0}$ for in situ remediation is seriously limited by the intrinsic formation of voluminous iron corrosion products (Tratnyek and Johnson 2006; Comba et al. 2011; Gheju 2011; Truex et al. 2011a, b). Bearing this in mind, the next section suggests an alternative nano- $\mathrm{Fe}^{0}$ subsurface deployment mechanism that more effectively takes into account the aforementioned nano- $\mathrm{Fe}^{0}$ hydraulic mobility issues than conventional injection processes: the formation of a nano- $\mathrm{Fe}^{0}$ "redox front" injection array system for progressive contaminant reduction. The geochemical process of redox front migration is a welldocumented one (Fryar and Schwartz 1998; Min et al. 2005; Sidborn and Neretnieks 2007).

5.2 Nano- $\mathrm{Fe}^{0}$ as Source of $\mathrm{Fe}^{\mathrm{II}}$ for a Redox Front?

\subsubsection{The Concept}

The progressive consumption of $\mathrm{mm}-\mathrm{Fe}^{0}$ (Fig. 1; Table 3 ) is the guarantee for the long-term efficiency of reactive barriers (Comba et al. 2011). In fact, continuously generated small amount of high reactive iron minerals ( $\mathrm{Gu}$ et al. 1999; Su and Puls 2001; Furukawa et al. 2002; Kohn et al. 2005; Noubactep 2007, 2008, 2010c, 2011b, c, d) are sufficient for the removal of contaminants which are present in trace amounts (Palmer and Wittbrodt 1991). As discussed above, for nano- $\mathrm{Fe}^{0}$ however, (1) $\mathrm{Fe}^{0}$ reactive exhaustion typically occurs in a relatively short time scale $(<9 \mathrm{~h})$ and $(2)$ it is likely that nano- $\mathrm{Fe}^{0}$ subsurface mobility is significantly retarded or even prevented due to the volumetric expansive nature of iron corrosion (Zhao et al. 2011). As a consequence an alternative method of subsurface deployment is suggested in the current work: the deployment of a linear nano- $\mathrm{Fe}^{0}$ injection array orientated perpendicular to the flow direction of the contaminant plume. The injected nano- $\mathrm{Fe}^{0}$ can effectively form a redox front (roll-front) which migrates through the contaminated zone and transforms the contaminants during its migration as illustrated in Fig. 5. The $\mathrm{Fe}^{\mathrm{II}} / \mathrm{Fe}^{\mathrm{III}}$ rollfront travels across the contaminated zone with all possible mechanisms (e.g. diffusion, dispersion, con- vection and preferential flow) and the contaminants are transformed and immobilized during the cycle $\mathrm{Fe}^{\mathrm{II}} \Leftrightarrow \mathrm{Fe}^{\mathrm{III}}$. In other words, it is a plume of $\mathrm{Fe}^{\mathrm{II}} / \mathrm{Fe}^{\mathrm{III}}$ formed from injected nano- $\mathrm{Fe}^{0}$ which migrates through the contaminated zone and "sweeps" the contaminants. As a consequence this method considers all nano-Fe ${ }^{0}$ mobility issues.

\subsubsection{Nano- $\mathrm{Fe}^{0}$ as $\mathrm{Fe}^{I I}$ Generator}

Nano- $\mathrm{Fe}^{0}$ in the aqueous phase is certainly a $\mathrm{Fe}^{\mathrm{II} /}$ $\mathrm{Fe}^{\mathrm{III}}$ producer. $\mathrm{Fe}^{\mathrm{II}}$ species are the main reducing agents for contaminants under both anoxic and oxic conditions (Stratmann and Müller 1994; Nesic 2007; Kiser and Manning 2010; Noubactep 2010c, 2011c, d; Zhuang et al. 2011). Microbial activity could regenerate $\mathrm{Fe}^{\mathrm{II}}$ (bio-corrosion) for more contaminant reduction (Vodyanitskii 2010). In this case, more contaminant is reduced than can be predicted from the reaction stoichiometry. In order words, the operating mode of nano- $\mathrm{Fe}^{0}$ for contaminant reduction can be summarized as follows: (1) $\mathrm{Fe}^{0}$ is oxidized to produce $\mathrm{Fe}^{\mathrm{II}}$, (2) $\mathrm{Fe}^{\mathrm{II}}$ reduces the contaminant and is oxidized to $\mathrm{Fe}^{\mathrm{III}}$ and (3) a proportion of $\mathrm{Fe}^{\mathrm{II}}$ is regenerated by the biological reduction of $\mathrm{Fe}^{\mathrm{III}}$. Accordingly, before $\mathrm{Fe}^{0}$ depletion, there are three sources of $\mathrm{Fe}^{\mathrm{II}}$ : (1) the $\mathrm{Fe}^{0}$-mediated abiotic oxidation by $\mathrm{H}_{2} \mathrm{O}$, (2) the $\mathrm{Fe}^{0}$-mediated abiotic oxidation by $\mathrm{Fe}^{\mathrm{III}}$ and (3) the biological reduction of $\mathrm{Fe}^{\mathrm{III}}$. After $\mathrm{Fe}^{0}$ depletion, the only remaining source of $\mathrm{Fe}^{\mathrm{II}}$ is the biological reduction of $\mathrm{Fe}^{\mathrm{III}}$. Provided that the appropriate microorganism species are present in the subsurface, this process, however, could conceptually proceed for a significantly long-time period (Cullen et al. 2011).

Evidence suggests that such micro-organism colonies can be sustained by a consistent supply of $\mathrm{Fe}^{\mathrm{II}}$, $\mathrm{Fe}^{\mathrm{III}}$ and molecular hydrogen $\left(\mathrm{H} / \mathrm{H}_{2}\right)$. Another further process that is worth noting is the generation of atomic or molecular hydrogen $\left(\mathrm{H} / \mathrm{H}_{2}\right)$ by $\mathrm{Fe}^{0}$-mediated hydrolysis reactions, which is likely to aid and the aforementioned biotic processes (Cullen et al. 2011).

The abiotic conversion of $\mathrm{Fe}^{\mathrm{III}}$ to $\mathrm{Fe}^{\mathrm{II}}$ has been successfully utilised in the hydrometallurgy industry, for example Lottering et al. (2008) reported on the sustainable use of $\mathrm{MnO}_{2}$ for the abiotic regeneration of $\mathrm{Fe}^{\mathrm{III}}$ for $\mathrm{U}^{\mathrm{IV}}$ oxidation.

The fate of contaminant reduction products is discussed in the next section. 
Fig. 5 Schematic diagram of the flow process of the U-shaped redox front through a contaminated zone. Despite the relative importance of preferential flow paths, contaminants are "swept" by the roll-front. The red circle is the contaminated zone. This zone is transformed to blue the circle upon treatment by the $\mathrm{Fe}^{\mathrm{II}} / \mathrm{Fe}^{\mathrm{III}}$ front
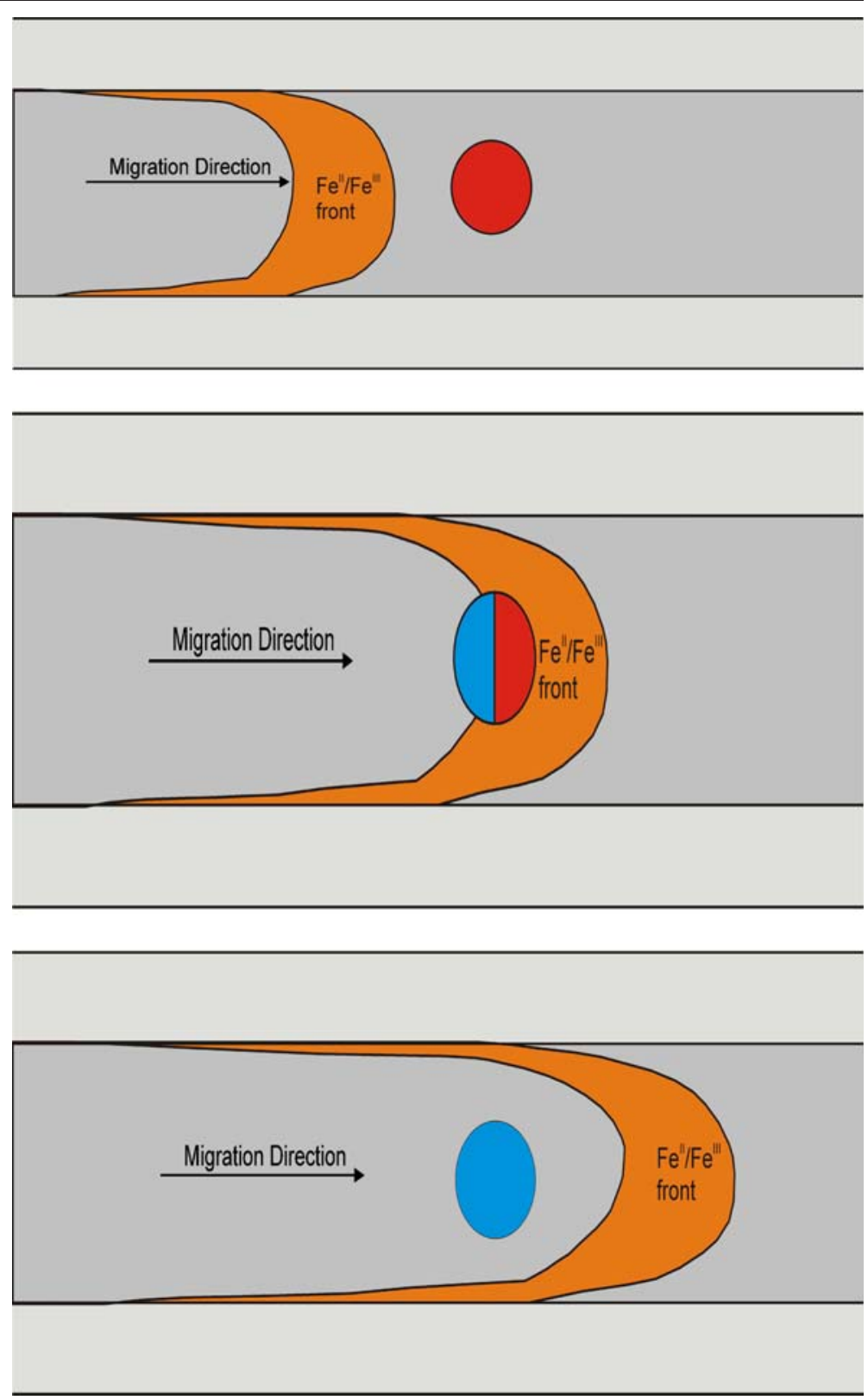

5.3 Mechanism of Contaminant Removal by Injected Nano-Fe ${ }^{0}$

The successful application of nano- $\mathrm{Fe}^{0}$ injection technology for in situ remediation is highly dependent on a comprehensive understanding of the fundamental processes governing the processes of contaminant removal. The hitherto discussion has focused on reductive transformations by nano- $\mathrm{Fe}^{0}$. However, contaminant reductive transformation is not a guaran- tee for contaminant removal (Noubactep 2010c, 2011c). Additionally, certain reaction products are more toxic than their parent compounds (Jiao et al. 2009). Accordingly, efforts have to be focused on the specific mechanism of aqueous contaminant removal. Relevant removal processes include: (1) adsorption, (2) chemical precipitation, (3) co-precipitation, (4) size exclusion or straining and (5) volatilization (Crawford et al. 1993a, b; Noubactep 2007, 2008, 2010c; Vodyanitskii 2010; Eusterhues et al. 2011; 
Johnson et al. 2011; Noubactep 2011d, e). Chemical precipitation is a characteristic of inorganic compounds when the solubility limit is exceeded (Crawford et al. 1993a, b; Kalin et al. 2005). Volatilization is subsequent to chemical transformation yielding gaseous species like $\mathrm{AsH}_{3}, \mathrm{CH}_{4}, \mathrm{CO}_{2}, \mathrm{H}_{2}$ and $\mathrm{N}_{2}$. In $\mathrm{Fe}^{0}$ reactive barrier systems, contaminants are efficiently removed by the combination of adsorption, coprecipitation and size exclusion within the engineered barrier (Noubactep 2010d; Noubactep and Schöner 2010; Noubactep 2011a). As a result the current discussion concentrates on such processes.

With $\mathrm{Fe}^{0}\left(<1 \mathrm{~m}^{2} / \mathrm{g}\right)$ first transformed to voluminous hydroxides species $\left(>100 \mathrm{~m}^{2} / \mathrm{g}\right)$ and subsequently transformed to oxides $\left(<40 \mathrm{~m}^{2} / \mathrm{g}\right)$, contaminant size exclusion (straining) is driven by the dynamic cycle of expansion/compression accompanying the corrosion process (Pokhrel and Viraraghavan 2008; Vodyanitskii 2010; Noubactep 2011a). During these cycles contaminants are enmeshed and sequestrated in a "matrix" of iron corrosion products.

For conventional nano- $\mathrm{Fe}^{0}$ injection arrays, size exclusion may play an important role (1) in proximity for $\mathrm{Fe}^{0}$ particles and (2) by reducing the pore space during expansive corrosion of the materials. However, if roll-fronts are formed as discussed above, the extent of permeability loss in aquifer will be limited. The roll-front could act as a colloidal reactive barrier for the removal of parent contaminants and reaction products. Species are removed or immobilized by colloids and not because they are reduced. More research is needed to test this hypothesis.

\subsection{1 $\mathrm{Fe}^{I I} / \mathrm{Fe}^{I I I}$ Redox Front as a Colloidal Reactive Barrier}

Aqueous contaminants have been reported to be quantitatively removed both during abiotic and biotic (1) oxidation of $\mathrm{Fe}^{\mathrm{II}}$ and (2) reduction of $\mathrm{Fe}^{\mathrm{III}}$ (Pokhrel and Viraraghavan 2008; 2009; Pokhrel et al. 2009; Vodyanitskii 2010). On the other hand, injection of $\mathrm{Fe}^{\mathrm{III}}$ salts for adsorptive contaminant removal has been reported (Morrison and Sprangler 1993; Morrison et al. 1996). Accordingly, the migration of the $\mathrm{Fe}^{\mathrm{II}} / \mathrm{Fe}^{\mathrm{III}}$ redox front may be coupled to quantitative contaminant removal by adsorption and co-precipitation.

The primary reason for contaminant removal during these redox reactions is the colloidal nature of in situ generated $\mathrm{Fe}$ species $\left(\mathrm{Fe}(\mathrm{OH})_{2}\right.$ and $\mathrm{Fe}$ $(\mathrm{OH})_{3}$ ) (Hanna and Boily 2010), which necessarily experience volumetric contraction to form oxides (of $\mathrm{Fe}^{\mathrm{II}}$ or $\mathrm{Fe}^{\mathrm{III}}$ ). Contaminants are first adsorbed by highly reactive colloids and are co-precipitated during transformation to amorphous and crystalline oxides (Ghauch et al. 2010; Noubactep 2011c, d).

\section{Concluding Remarks}

Constructed geochemical barriers of metallic iron $\left(\mathrm{Fe}^{0}\right)$ have been used for groundwater remediation since 1996 (O'Hannesin and Gillham 1998; Scherer et al. 2000; Henderson and Demond 2007; Gillham 2010, Comba et al. 2011; Gheju 2011). In recent years, however, nano- $\mathrm{Fe}^{0}$ has received proclaim as a new tool for water treatment due to (1) improvements in reactivity and associated aqueous contaminant removal performance compared with conventional materials and (2) the option of subsurface deployment via injection for targeted in situ treatment of contaminant plumes (Comba et al. 2011; Gheju 2011).

Considering reactivity first, the current work has highlighted the need for prudent use of terminology. Discounting any quantum size effects, which are only prevalent for $\mathrm{Fe}^{0}$ less than approximately $10 \mathrm{~nm}$ in diameter, the reactivity of nano- $\mathrm{Fe}^{0}$ as a function of surface area is no more reactive than larger forms. Nano-Fe ${ }^{0}$ only exhibits such high reactivity due to it significantly high surface area as a function of mass/ volume. Despite this, a recent trend in research has been the development of bimetallic nano- $\mathrm{Fe}^{0}$ wherein the combination of a noble metal acts to further increase the reactivity of nano- $\mathrm{Fe}^{0}$. It is argued in the current work that as reactive exhaustion is already achieved by monometallic nano- $\mathrm{Fe}^{0}$ in the order of minutes this seems counterintuitive for the majority of environmental applications.

Considering the nano- $\mathrm{Fe}^{0}$ subsurface injection procedure, in the current work it has been highlighted that the hydraulic mobility of the particles is likely to be significantly retarded by voluminous expansion due to particle corrosion. An alternative nano- $\mathrm{Fe}^{0}$ injection procedure has been suggested herein. The injected nano- $\mathrm{Fe}^{0}$ effectively forms an in situ migrating front which possibly reductively transforms contaminant and removes reduced species by adsorption and co-precipitation. 
It is also outlined in the current work that a number of studies with experiments "proclaimed" as analogous to environmental systems are largely overlooked a range of operational drivers including changes in nano- $\mathrm{Fe}^{0}$ (1) reactivity and (2) voluminous as a function of time. It is hoped that the huge literature on redox front migration (Reynolds and Goldhaber 1978; Posey-Dowty et al. 1987; Romero et al. 1992; Read et al. 1993) and the cycle of iron in the hydrosphere (Vodyanitskii 2010) will now be used for the further development of nano- $\mathrm{Fe}^{0}$ injection technology.

Acknowledgements Mohammad A. Rahman (Angewandte Geologie-Universität Göttingen) is acknowledged for technical support.

Open Access This article is distributed under the terms of the Creative Commons Attribution Noncommercial License which permits any noncommercial use, distribution, and reproduction in any medium, provided the original author(s) and source are credited.

\section{References}

Agarwal, A., \& Joshi, H. (2010). Environmental sciences application of nanotechnology in the remediation of contaminated groundwater: a short review. Recent Research in Science and Technology, 2, 51-57.

Allaire, S. E., Roulier, S., \& Cessna, A. J. (2009). Quantifying preferential flow in soils: a review of different techniques. Journal of Hydrology, 378, 179-204.

Anstice, C., Alonso, C., \& Molina, F. J. (1993). Cover cracking as a function of bar corrosion: part I-experimental test. Materials and Structures, 26, 453-464.

Antia, D. D. J. (2011). Modification of aquifer pore-water by static diffusion using nano-zero-valent metals. Water 12, 3, 79-112.

Barnes, R. J., van der Gast, C. J., Riba, O., Lehtovirta, L. E., Prosser, J. I., Dobson, P. J., et al. (2010). The impact of zero-valent iron nanoparticles on a river water bacterial community. Journal of Hazardous Materials, 184, 73-80.

Bartzas, G., \& Komnitsas, K. (2010). Solid phase studies and geochemical modelling of low-cost permeable reactive barriers. Journal of Hazardous Materials, 183, 301-308.

Behrens, S. H., Christl, D. I., Emmerzael, R., Schurtenberger, P., \& Borkovec, M. (2000). Charging and aggregation properties of carboxyl latex particles: experiments versus DLVO theory. Langmuir, 21, 2566-2575.

Blowes, D. W., Ptacek, C. J., \& Jambor, J. L. (1997). In-situ remediation of $\mathrm{Cr}(\mathrm{VI})$-contaminated groundwater using permeable reactive walls: laboratory studies. Environmental Science \& Technology, 31, 3348-3357.

Boparai, H. K., Joseph, M., \& O'Carroll, D. M. (2011). Kinetics and thermodynamics of cadmium ion removal by adsorption onto nano zerovalent iron particles. Journal of Hazardous Materials, 186, 458-465.

Caré, S., Nguyen, Q. T., L'Hostis, V., \& Berthaud, Y. (2008). Mechanical properties of the rust layer induced by impressed current method in reinforced mortar. Cement and Concrete Research, 38, 1079-1091.

Celebi, O., Uzum, C., Shahwan, T., \& Erten, H. N. (2007). A radiotracer study of the adsorption behavior of aqueous $\mathrm{Ba}^{2+}$ ions on nanoparticles of zero-valent iron. Journal of Hazardous Materials, 148, 761-767.

Chen, K.-F., Li, S., \& Zhang, W.-X. (2011). Renewable hydrogen generation by bimetallic zerovalent iron nanoparticles. Chemical Engineering Journal, 170, 562-567.

Clothier, B. E., Green, S. R., \& Deurer, M. (2008). Preferential flow and transport in soil: progress and prognosis. European Journal of Soil Science, 59, 2-13.

Comba, S., Di Molfetta, A., \& Sethi, R. (2011). A comparison between field applications of nano-, micro-, and millimetric zero-valent iron for the remediation of contaminated aquifers. Water, Air, and Soil Pollution, 215, 595-607.

Courcelles, B., Modaressi-Farahmand-Razavi, A., Gouvenot, D., \& Esnault-Filet, A. (2011). Influence of precipitates on hydraulic performance of permeable reactive barrier filters. International Journal of Geomechanics, 11, 142-151.

Crane, R. A., Dickinson, M., Popescu, I. C., \& Scott, T. B. (2011). Magnetite and zero-valent iron nanoparticles for the remediation of uranium contaminated environmental water. Water Research, 45, 2931-2942.

Crawford, R. J., Harding, I. H., \& Mainwaring, D. E. (1993a). Adsorption and coprecipitation of single heavy metal ions onto the hydrated oxides of iron and chromium. Langmuir, 9, 3050-3056.

Crawford, R. J., Harding, I. H., \& Mainwaring, D. E. (1993b). Adsorption and coprecipitation of multiple heavy metal ions onto the hydrated oxides of iron and chromium. Langmuir, 9, 3057-3062.

Cullen, L. G., Tilston, E. L., Mitchell, G. R., Collins, C. D., \& Shaw, L. J. (2011). Assessing the impact of nano- and micro-scale zerovalent iron particles on soil microbial activities: Particle reactivity interferes with assay conditions and interpretation of genuine microbial effects. Chemosphere, 82, 1675-1682.

Diao, M., \& Yao, M. (2009). Use of zero-valent iron nanoparticles in inactivating microbes. Water Research, 43, 5243-5251

Dickinson, M., \& Scott, T. B. (2010). The application of zerovalent iron nanoparticles for the remediation of a uraniumcontaminated waste effluent. Journal of Hazardous Materials, $178,171-179$.

Eusterhues, K., Rennert, T., Knicker, H., Kgel-Knabner, I., Totsche, K. U., \& Schwertmann, U. (2011). Fractionation of organic matter due to reaction with ferrihydrite: coprecipitation versus adsorption. Environmental Science \& Technology, 45, 527-533.

Fang, Z., Qiu, X., Chen, J., \& Qiu, X. (2011). Degradation of the polybrominated diphenyl ethers by nanoscale zerovalent metallic particles prepared from steel pickling waste liquor. Desalination, 267, 34-41.

Fernando, W. J. N., Ahmad, A. L., Abd. Shukor, S. R., \& Lok, Y. H. (2008). A model for constant temperature drying 
rates of case hardened slices of papaya and garlic. Journal of Food Engineering, 88, 229-238.

Flury, M., \& Flühler, H. (1994). Brilliant Blue FCF as a dye tracer for solute transport studies. A toxicological review. Journal of Environmental Quality, 23, 1108-1112.

Fryar, A. E., \& Schwartz, F. W. (1998). Hydraulic-conductivity reduction, reaction-front propagation, and preferential flow within a model reactive barrier. Journal of Contaminant Hydrology, 32, 333-351.

Furukawa, Y., Kim, J.-W., Watkins, J., \& Wilkin, R. T. (2002). Formation of ferrihydrite and associated iron corrosion products in permeable reactive barriers of zerovalent iron. Environmental Science \& Technology, 36, 5469-5475.

Ghauch, A., Tuqan, A., \& Abou, A. H. (2009). Antibiotic removal from water: elimination of amoxicillin and ampicillin by microscale and nanoscale iron particles. Environmental Pollution, 157, 1626-1635.

Ghauch, A., Abou, A. H., \& Bdeir, S. (2010). Aqueous removal of diclofenac by plated elemental iron: bimetallic systems. Journal of Hazardous Materials, 182, 64-74.

Gheju, M. (2011). Hexavalent chromium reduction with zerovalent iron (ZVI) in aquatic systems. Water, Air, and Soil Pollution. doi:10.1007/s11270-011-0812-y.

Gillham, R. W. (2003). Discussion of Papers/Discussion of nano-scale iron for dehalogenation (by Evan K. Nyer and David B. Vance (2001), Ground Water Monitoring \& Remediation, 21(2), pp. 41-54). Ground Water Monitoring \& Remediation, 23, 6-8.

Gillham, R.W. (2010). Development of the granular iron permeable reactive barrier technology (good science or good fortune). In Y. Chen, X. Tang, L. Zhan (Eds.), "Advances in environmental geotechnics: proceedings of the International Symposium on Geoenvironmental Engineering in Hangzhou, China, September 8-10, 2009" (pp 5-15). London: Springer.

Gillham, R. W., \& O'Hannesin, S. F. (1991). Metal-catalysed abiotic degradation of halogenated organic compounds. Ground Water, 29, 752-761.

Gillham, R. W., \& O'Hannesin, S. F. (1994). Enhanced degradation of halogenated aliphatics by zero-valent iron. Ground Water, 32, 958-967.

Grieger, K. D., Fjordboge, A., Hartmann, N. B., Eriksson, E., Bjerg, P. L., \& Baun, A. (2010). Environmental benefits and risks of zero-valent iron nanoparticles (nZVI) for in situ remediation: Risk mitigation or trade-off? Journal of Contaminant Hydrology, 118, 165-183.

Gu, B., Phelps, T. J., Liang, L., Dickey, M. J., Roh, Y., Kinsall, B. L., et al. (1999). Biogeochemical dynamics in zerovalent iron columns: implications for permeable reactive barriers. Environmental Science \& Technology, 33, 21702177.

Hanna, K., \& Boily, J.-F. (2010). Sorption of two naphthoic acids to goethite surface under flow through conditions. Environmental Science \& Technology, 44, 8863-8869.

Henderson, A. D., \& Demond, A. H. (2007). Long-term performance of zero-valent iron permeable reactive barriers: a critical review. Environmental Engineering Science, 24, 401-423.

Jeen, S.-W., Gillham, R. B., \& Przepiora, A. (2011). Predictions of long-term performance of granular iron permeable reactive barriers: field-scale evaluation. Journal of Contaminant Hydrology, 123, 50-64.

Jiang, Z., Lv, L., Zhang, W., Du, Q., Pan, B., Yang, L., et al. (2011). Nitrate reduction using nanosized zero-valent iron supported by polystyrene resins: role of surface functional groups. Water Research, 45, 2191-2198.

Jiao, Y., Qiu, C., Huang, L., Wu, K., Ma, H., Chen, S., et al. (2009). Reductive dechlorination of carbon tetrachloride by zero-valent iron and related iron corrosion. Applied Catalysis B: Environmental, 91, 434-440.

Johnson, R. L., Thoms, R. B., Johnson, R. O. B., Nurmi, J., \& Tratnyek, P. G. (2008). Mineral precipitation upgradient from a zero-valent iron permeable reactive barrier. Ground Water Monitoring \& Remediation, 28, 56-64.

Johnson, W. P., Ma, H., \& Pazmino, E. (2011). Straining credibility: a general comment regarding common arguments used to infer straining as the mechanism of colloid retention in porous media. Environmental Science \& Technology, 45, 3831-3832.

Kadu, B. S., Sathe, Y. D., Ingle, A. B., Chikate, R. C., Patil, K. R., \& Rode, C. V. (2011). Efficiency and recycling capability of montmorillonite supported $\mathrm{Fe}-\mathrm{Ni}$ bimetallic nanocomposites towards hexavalent chromium remediation. Applied Catalysis B: Environmental, 104, 407-414.

Kalin, M., Wheeler, W. N., \& Meinrath, G. (2005). The removal of uranium from mining waste water using algal/ microbial biomass. Journal of Environmental Radioactivity, 78, 151-177.

Kanel, S. R., Greneche, J.-M., \& Choi, H. (2006). Arsenic(V) Removal from groundwater using nano scale zero-valent iron as a colloidal reactive barrier material. Environmental Science \& Technology, 40, 2045-2050.

Karn, B., Kuiken, T., \& Otto, M. (2009). Nanotechnology and in situ remediation: a review of the benefits and potential risks. Environmental Health Perspectives, 117, 18321831.

Kim, J. Y., Park, H.-J., Lee, C., Nelson, K. L., Sedlak, D. L., \& Yoon, J. (2010). Inactivation of Escherichia coli by nanoparticulate zerovalent iron and ferrous ion. Applied and Environmental Microbiology, 76, 7668-7670.

Kiser, J. R., \& Manning, B. A. (2010). Reduction and immobilization of chromium(VI) by iron(II)-treated faujasite. Journal of Hazardous Materials, 174, 167-174.

Kohn, T., Kenneth, J. T., Livi, A., Roberts, A. L., \& Vikesland, P. J. (2005). Longevity of granular iron in groundwater treatment processes: corrosion product development. Environmental Science \& Technology, 39, 2867-2879.

Korte, N. E., Zutman, J. L., Schlosser, R. M., Liang, L., Gu, B., \& Fernando, Q. (2000). Field application of palladized iron for the dechlorination of trichloroethene. Waste Management, 20, 687-694.

Li, L., \& Benson, C. H. (2010). Evaluation of five strategies to limit the impact of fouling in permeable reactive barriers. Journal of Hazardous Materials, 181, 170-180.

Li, X. Q., \& Zhang, W. X. (2007). Sequestration of metal cations with zerovalent iron nanoparticles - a study with high resolution X-ray photoelectron spectroscopy (HRXPS). Journal of Physical Chemistry C, 111, 69396946.

Li, X. Q., Elliott, D. W., \& Zhang, W. X. (2006). Zero-valent iron nanoparticles for abatement of environmental pollu- 
tants: materials and engineering aspects. Critical Reviews in Solid State and Materials Sciences, 31, 111-122.

Litter, M. I., Morgada, M. E., \& Bundschuh, J. (2010). Possible treatments for arsenic removal in Latin American waters for human consumption. Environmental Pollution, 158, 1105-1118.

Lottering, M. J., Lorenzen, L., Phala, N. S., Smit, J. T., \& Schalkwyk, G. A. C. (2008). Mineralogy and uranium leaching response of low grade South African ores. Minerals Engineering, 21, 16-22.

Macé, C. (2006). Controlling groundwater VOCs: do nanoscale ZVI particles have any advantages over microscale ZVI or BNP? Pollution Engineering, 38, 24-27.

Macé, C., Desrocher, S., Gheorghiu, F., Kane, A., Pupeza, M., Cernik, M., et al. (2006). Nanotechnology and groundwater remediation: a step forward in technology understanding. Remediation, 16, 23-33.

Mackay, M. D., \& Cherry, J. A. (1989). Groundwater contamination: pump-and-treat remediation. Environmental Science \& Technology, 23, 630-636.

Masciangioli, T., \& Zhang, W. X. (2003). Environmental technologies at the nanoscale. Environmental Science \& Technology, 37, 102A-108A.

Matheson, L. J., \& Tratnyek, P. G. (1994). Reductive dehalogenation of chlorinated methanes by iron metal. Environmental Science \& Technology, 28, 2045-2053.

McMurty, D. C., \& Elton, R. O. (1985). New approach to in-situ treatment of contaminated groundwaters. Environmental Progress, 4, 168-170.

Min, M., Xu, H., Chen, J., \& Fayek, M. (2005). Evidence of uranium biomineralization in sandstone-hosted roll-front uranium deposits, northwestern China. Ore Geology Reviews, 26, 198-206.

Moraci, N., \& Calabrò, P. S. (2010). Heavy metals removal and hydraulic performance in zero-valent iron/pumice permeable reactive barriers. Journal of Environmental Management, 91, 2336-2341.

Morrison, J. S., \& Sprangler, R. R. (1993). Chemical barriers for controlling groundwater contamination. Environmental Progress, 12, 175-181.

Morrison, J. S., Sprangler, R. R., \& Morris, S. A. (1996). Subsurface injection of dissolved ferric chloride to form a chemical barrier: laboratory investigations. Ground Water, 34, 75-83.

Mossa, H. S., Ataie-Ashtiani, B., \& Kholghi, M. (2011). Nitrate reduction by nano- $\mathrm{Fe} / \mathrm{Cu}$ particles in packed column. Desalination. doi:10.1016/j.desal.2011.03.051.

Muftikian, R., Fernando, Q., \& Korte, N. (1995). A method for the rapid dechlorination of low molecular weight chlorinated hydrocarbons in water. Water Research, 29, 2434-2439.

Müller, N., \& Nowack, B. (2010). Nano zero valent iron-THE solution for water and soil remediation?. Report of workshop held in Zurich (Switzerland), November 24th 2009. http://www.observatorynano.eu/project/filesystem/ files/nZVI_final_vsObservatory.pdf. (Access 2011/04/24).

Nagpal, V., Bokare, A. D., Chikate, R. C., Rode, C. V., \& Paknikar, K. M. (2010). Reductive dechlorination of $\gamma$ hexachlorocyclohexane using Fe-Pd bimetallic nanoparticles. Journal of Hazardous Materials, 175, 680-687.

Nagpal, V., Bokare, A. D., Chikate, R. C., Rode, C. V., \& Paknikar, K. M. (2011). Reply to comment on "Reductive dechlorination of $\gamma$-hexachlorocyclohexane using $\mathrm{Fe}-\mathrm{Pd}$ bimetallic nanoparticles", by C. Noubactep. Journal of Hazardous Materials. doi:10.1016/j.jhazmat.2011.04.015.

Nesic, S. (2007). Key issues related to modelling of internal corrosion of oil and gas pipelines - a review. Corrosion Science, 49, 4308-4338.

Noubactep, C. (2007). Processes of contaminant removal in " $\mathrm{Fe}^{0}-\mathrm{H}_{2} \mathrm{O}$ " systems revisited: the importance of coprecipitation. Open Environmental Journal, 1, 9-13.

Noubactep, C. (2008). A critical review on the mechanism of contaminant removal in $\mathrm{Fe}^{0}-\mathrm{H}_{2} \mathrm{O}$ systems. Environmental Technology, 29, 909-920.

Noubactep, C. (2010a). The suitability of metallic iron for environmental remediation. Environmental Progress \& Sustainable Energy, 29, 286-291.

Noubactep, C. (2010b). Elemental metals for environmental remediation: learning from cementation process. Journal of Hazardous Materials, 181, 1170-1174.

Noubactep, C. (2010c). The fundamental mechanism of aqueous contaminant removal by metallic iron. Water $S A$, 36, 663-670.

Noubactep, C. (2010d). Metallic iron for safe drinking water worldwide. Chemical Engineering Journal, 165, 740-749.

Noubactep, C. (2011a). Metallic iron for safe drinking water production, Freiberg Online Geology 27, 38 pp, ISSN 1434-7512. Available at: www.geo.tu-freiberg.de/fog.

Noubactep, C. (2011b). Comment on "Reductive dechlorination of g-hexachloro-cyclohexane using Fe-Pd bimetallic nanoparticles" by Nagpal et al [J. Hazard. Mater. 175 (2010) 680-687]. Journal of Hazardous Materials. doi:10.1016/j.jhazmat.2011.03.081.

Noubactep, C. (2011c). Aqueous contaminant removal by metallic iron: is the paradigm shifting? Water SA, 37, 419-426.

Noubactep, C. (2011d). Metallic iron for water treatment: a knowledge system challenges mainstream science. Fresenius Environmental Bulletin 20, 2632-2637.

Noubactep, C. (2011e). On the mechanism microbe inactivation by metallic iron. Journal of Hazardous Materials. doi:10.1016/j.jhazmat.2011.08.063.

Noubactep, C., \& Caré, S. (2010a). Dimensioning metallic iron beds for efficient contaminant removal. Chemical Engineering Journal, 163, 454-460.

Noubactep, C., \& Caré, S. (2010b). On nanoscale metallic iron for groundwater remediation. Journal of Hazardous Materials, 182, 923-927.

Noubactep, C., \& Schöner, A. (2010). Metallic iron: dawn of a new era of drinking water treatment research? Fresenius Environmental Bulletin, 19, 1661-1668.

Noubactep, C., Licha, T., Scott, T. B., Fall, M., \& Sauter, M. (2009). Exploring the influence of operational parameters on the reactivity of elemental iron materials. Journal of Hazardous Materials, 172, 943-951.

Noubactep, C., Caré, S., Togue-Kamga, F., Schöner, A., \& Woafo, P. (2010). Extending service life of household water filters by mixing metallic iron with sand. Clean-Soil, Air, Water, 38, 951-959.

O'Hannesin, S. F., \& Gillham, R. W. (1998). Long-term performance of an in situ "iron wall" for remediation of VOCs. Ground Water, 36, 164-170.

Palmer, C. D., \& Wittbrodt, P. R. (1991). Processes affecting the remediation of chromium-contaminated sites. Environmental Health Perspectives, 92, 25-40. 
Peralta-Videa, J. R., Zhao, L., Lopez-Moreno, M. L., de la Rosa, G., Hong, J., \& Gardea-Torresdey, J. L. (2011). Nanomaterials and the environment: a review for the biennium 2008-2010. Journal of Hazardous Materials, 186, 1-15.

Pokhrel, D., \& Viraraghavan, T. (2008). Arsenic removal in an iron oxide-coated fungal biomass column: analysis of breakthrough curves. Bioresource Technology, 99, 20672071.

Pokhrel, D., \& Viraraghavan, T. (2009). Biological filtration for removal of arsenic from drinking water. Journal of Environmental Management, 90, 1956-1961.

Pokhrel, D., Bhandari, B. S., \& Viraraghavan, T. (2009). Arsenic contamination of groundwater in the Terai region of Nepal: an overview of health concerns and treatment options. Environment International, 35, 157-161.

Ponder, S. M., Darab, J. G., \& Mallouk, T. E. (2000). Remediation of $\mathrm{Cr}(\mathrm{VI})$ and $\mathrm{Pb}(\mathrm{II})$ aqueous solutions using supported, nanoscale zero-valent iron. Environmental Science \& Technology, 34, 2564-2569.

Posey-Dowty, J., Axtmann, E., Crerar, D., Borcsik, M., Ronk, A., \& Woods, W. (1987). Dissolution rate of uraninite and uranium roll-front ores. Economic Geology, 82, 184-194.

Pradeep, T., \& Anshup. (2009). Noble metal nanoparticles for water purification: a critical review. Thin Solid Films, 517, 6441-6478.

Read, D., Lawless, T. A., Sims, R. J., \& Butter, K. R. (1993). Uranium migration through intact sandstone cores. Journal of Contaminant Hydrology, 13, 277-289.

Reardon, E. J., Fagan, R., Vogan, J. L., \& Przepiora, A. (2008). Anaerobic corrosion reaction kinetics of nanosized iron. Environmental Science \& Technology, 42, 2420-2425.

Reynolds, R. L., \& Goldhaber, M. B. (1978). Origin of a south Texas roll-type uranium deposit: I. Alteration of iron-titanium oxide minerals. Economic Geology, 73, 1677-1689.

Romero, L., Neretnieks, I., \& Moreno, L. (1992). Movement of the redox front at the Osamu Utsumi uranium mine, Poços de Caldas, Brazil. Journal of Geochemical Exploration, 45, 471-501.

Sakulchaicharoen, N., O'Carroll, D. M., \& Herrera, J. E. (2010). Enhanced stability and dechlorination activity of pre-synthesis stabilized nanoscale FePd particles. Journal of Contaminant Hydrology, 118, 117-127.

Scherer, M. M., Richter, S., Valentine, R. L., \& Alvarez, P. J. J. (2000). Chemistry and microbiology of permeable reactive barriers for in situ groundwater clean up. Reviews in Environmental Science \& Technology, 30, 363-411.

Schrick, B., Blough, J. L., Jones, A. D., \& Mallouk, T. E. (2002). Hydrodechlorination of trichloroethylene to hydrocarbons using bimetallic nickel-iron nanoparticles. Chemistry of Materials, 14, 5140-5147.

Shi, Z., Nurmi, J. T., \& Tratnyek, P. G. (2011). Effects of nano zero-valent iron on oxidation-reduction potential. Environmental Science \& Technology, 45, 1586-1592.

Sidborn, M., \& Neretnieks, I. (2007). Long term redox evolution in granitic rocks: modelling the redox front propagation in the rock matrix. Applied Geochemistry, 22, 2381-2396.

Simunek, J., Jarvis, N. J., van Genuchten, M. T., \& Gardenas, A. (2003). Review and comparison of models for describing non-equilibrium and preferential flow and transport in the vadose zone. Journal of Hydrology, 272, 14-35.

Starr, R. C., \& Cherry, J. A. (1994). In situ remediation of contaminated ground water: the funnel-and-Gate System. Ground Water, 32, 465-476.

Stratmann, M., \& Müller, J. (1994). The mechanism of the oxygen reduction on rust-covered metal substrates. Corrosion Science, 36, 327-359.

Su, C., \& Puls, R. W. (2001). Arsenate and arsenite removal by zerovalent iron: kinetics, redox transformation, and implications for in situ groundwater remediation. Environmental Science \& Technology, 35, 4562-4568.

Tarvainen, V., Ranta-Maunus, A., Hanhijärvi, A., \& Forsén, H. (2006). The effect of drying and storage conditions on case hardening of scots pine and norway spruce timber. Maderas Ciencia y tecnología, 8, 3-14.

Tervonen, T., Linkov, I., Figueira, J. R., Steevens, J., Chappell, M., \& Merad, M. (2009). Risk-based classification system of nanomaterials. Journal of Nanoparticle Research, 11, 757-766.

Tong, M., Yuan, S., Long, H., Zheng, M., Wang, L., \& Chen, J. (2011). Reduction of nitrobenzene in groundwater by iron nanoparticles immobilized in PEG/nylon membrane. Journal of Contaminant Hydrology, 122, 16-25.

Tratnyek, P. G., \& Johnson, R. L. (2006). Nanotechnologies for environmental cleanup. Nano Today, 1, 44-48.

Truex, M. J., Macbeth, T. W., Vermeul, V. R., Fritz, B. G., Mendoza, D. P., Mackley, R. D., et al. (2011). Demonstration of combined zero-valent iron and electrical resistance heating for in situ trichloroethene remediation. Environmental Science \& Technology, 45, 5346-5351.

Truex, M. J., Vermeul, V. R., Mendoza, D. P., Fritz, B. G., Mackley, R. D., Oostrom, M., et al. (2011). Injection of zero-valent iron into an unconfined aquifer using shearthinning fluids. Ground Water Monitoring \& Remediation., $31,50-58$.

Vodyanitskii, Y. N. (2010). The role of iron in the fixation of heavy metals and metalloids in soils: a review of publications. Eurasian Soil Science, 43, 519-532.

Wang, C.-B., \& Zhang, W.-X. (1997). Synthesizing nanoscale iron particles for rapid and complete dechlorination of TCE and PCBs. Environmental Science \& Technology, 31, 2154-2156.

Wu, Y., Zhang, J., Tong, Y., \& Xu, X. (2009). Chromium (VI) reduction in aqueous solutions by $\mathrm{Fe}_{3} \mathrm{O}_{4}$-stabilized $\mathrm{Fe}^{0}$ nanoparticles. Journal of Hazardous Materials, 172, 1640-1645.

Xiao, S., Ma, H., Shen, M., Wang, S., Huang, Q., \& Shi, X. (2011). Excellent copper(II) removal using zero-valent iron nanoparticle - immobilized hybrid electrospun polymer nanofibrous mats. Colloids and Surfaces A: Physicochemical and Engineering Aspects, 381, 48-54.

Yuan, S., Zheng, Z., Meng, X.-Z., Chen, J., \& Wang, L. (2010). Surfactant mediated HCB dechlorination in contaminated soils and sediments by micro and nanoscale $\mathrm{Cu} / \mathrm{Fe}$ Particles. Geoderma, 159, 165-173.

Zhang, W.-X. (2003). Nanoscale iron particles for environmental remediation: an overview. Journal of Nanoparticle Research, 5, 323-332.

Zhang, W.-X., Wang, C.-B., \& Lien, H.-L. (1998). Treatment of chlorinated organic contaminants with 
nanoscale bimetallic particles. Catalalysis Today, 40, 387-395.

Zhao, Y., Ren, H., Dai, H., \& Jin, W. (2011). Composition and expansion coefficient of rust based on X-ray diffraction and thermal analysis. Corrosion Science, 53, 1646-1658.

Zhu, N., Luan, H., Yuan, S., Chen, J., Wu, X., \& Wang, L. (2010). Effective dechlorination of HCB by nanoscale $\mathrm{Cu}$ /
Fe particles. Journal of Hazardous Materials, 176, 11011105.

Zhuang, Y., Ahn, S., Seyfferth, A. L., Masue-Slowey, Y., Fendorf, S., \& Luthy, R. G. (2011). Dehalogenation of polybrominated diphenyl ethers and polychlorinated biphenyl by bimetallic, impregnated, and nanoscale zerovalent iron. Environmental Science \& Technology, 45, 48964903. 